\title{
Low uptake of COVID-19 prevention behaviours and high socioeconomic impact of lockdown measures in South Asia: evidence from a large-scale multi-country surveillance programme
}

Dian Kusuma ${ }^{1}$, Rajendra Pradeepa ${ }^{2}$, Khadija I Khawaja ${ }^{3}$, Mehedi Hasan ${ }^{4}$, Samreen Siddiqui ${ }^{5}$, Sara Mahmood ${ }^{3}$, Syed Mohsin Ali Shah ${ }^{6}$, Chamini $\mathrm{K}$ De Silva ${ }^{7}$, Laksara de Silva ${ }^{8}$, Manoja Gamage ${ }^{8}$, Menka Loomba ${ }^{5}$, Vindya P Rajakaruna ${ }^{7}$, Abu AM Hanif ${ }^{4}$, Rajan Babu Kamalesh ${ }^{2}$, Balachandran Kumarendran ${ }^{9}$, Marie Loh ${ }^{10,11}$, Archa Misra ${ }^{5}$, Asma Tassawar ${ }^{6}$, Akansha Tyagi ${ }^{5}$, Swati Waghdhare ${ }^{5}$, Saira Burney ${ }^{3}$, Sajjad Ahmad ${ }^{6}$, Viswanathan Mohan ${ }^{2}$, Malabika Sarker ${ }^{4}$, lan Y Goon ${ }^{11}$, Anuradhani Kasturiratne ${ }^{7}$, Jaspal S Kooner ${ }^{12}$, Prasad Katulanda ${ }^{8}$, Sujeet Jha ${ }^{5}$, Ranjit Mohan Anjana ${ }^{2}$, Malay K Mridha ${ }^{4}$, Franco Sassi ${ }^{1}$, John C Chambers ${ }^{10,11}$, on behalf of the NIHR Global Health Research Unit for Diabetes and Cardiovascular Disease in South Asia

1 Centre for Health Economics \& Policy Innovation, Imperial College Business School, UK

2 Madras Diabetes Research Foundation, Chennai, India

3 Services Institute of Medical Sciences, Lahore, Pakistan

4 BRAC James P Grant School of Public Health, BRAC University, Dhaka, Bangladesh

5 Max Healthcare, New Delhi, India

6 Punjab Institute of Cardiology, Lahore, Pakistan

7 Faculty of Medicine, University of Kelaniya, Ragama, Sri Lanka

8 Faculty of Medicine, University of Colombo, Colombo, Sri Lanka

9 Faculty of Medicine, University of Jaffna, Jaffna, Sri Lanka

10 Lee Kong Chian School of Medicine, Nanyang Technological University, Singapore, Singapore 11 School of Public Health, Imperial College London, London, UK

12 National Heart and Lung Institute, Imperial College London, London, UK

\section{Correspondence to}

John C Chambers

Department of Epidemiology and Biostatistics, School of Public Health, Imperial College London, London W2 1PG, UK

john.chambers@ic.ac.uk 
medRxiv preprint doi: https://doi.org/10.1101/2020.11.12.20229898; this version posted November 14, 2020. The copyright holder for this preprint (which was not certified by peer review) is the author/funder, who has granted medRxiv a license to display the preprint in perpetuity. All rights reserved. No reuse allowed without permission.

\section{Abstract}

Background. South Asia has become a major epicentre of the COVID-19 pandemic. Understanding South Asians' awareness, attitudes and experiences of early measures for the prevention of COVID-19 is key to improving the effectiveness and mitigating the social and economic impacts of pandemic responses at a critical time for the Region.

Methods. We assessed the knowledge, behaviours, health and socio-economic circumstances of 29,809 adult men and women, at 93 locations across four South Asian countries. Data were collected during the national lockdowns implemented from March to July 2020, and compared with data collected prior to the pandemic as part of an ongoing prospective surveillance initiative.

Results. Participants were $61 \%$ female, mean age 45.1 years. Almost half had one or more chronic disease, including diabetes (16\%), hypertension $(23 \%)$ or obesity $(16 \%)$. Knowledge of the primary COVID-19 symptoms and transmission routes was high, but access to hygiene and personal protection resources was low (running water 63\%, hand sanitisers 53\%, paper tissues 48\%). Key preventive measures were not widely adopted. Knowledge, access to, and uptake of COVID-19 prevention measures were low amongst people from disadvantaged socio-economic groups. Fifteen percent of people receiving treatment for chronic diseases reported loss of access to longterm medications; $40 \%$ reported symptoms suggestive of anxiety or depression. The prevalence of unemployment rose from $9.3 \%$ to $39.4 \%(P<0.001)$, and household income fell by $52 \%(P<0.001)$ during the lockdown. Younger people and those from less affluent socio-economic groups were most severely impacted. Sedentary time increased by $32 \%$ and inadequate fruit and vegetable intake increased by $10 \%$ ( $\mathrm{P}<0.001$ for both), while tobacco and alcohol consumption dropped by $41 \%$ and $80 \%$, respectively $(P<0.001)$, during the lockdown.

Conclusions. Our results identified important knowledge, access and uptake barriers to the prevention of COVID-19 in South Asia, and demonstrated major adverse impacts of the pandemic on chronic disease treatment, mental health, health-related behaviours, employment and household finances. We found important sociodemographic differences for impact, suggesting a widening of existing inequalities. Our findings underscore the need for immediate large-scale action to close gaps in knowledge and access to essential resources for prevention, along with measures to safeguard economic production and mitigate socio-economic impacts on the young and the poor. 
medRxiv preprint doi: https://doi.org/10.1101/2020.11.12.20229898; this version posted November 14, 2020. The copyright holder for this preprint (which was not certified by peer review) is the author/funder, who has granted medRxiv a license to display the preprint in perpetuity.

\section{Background}

South-Asia is the most densely populated region of the world (1.9 billion people, $25 \%$ of global population), with more than $98 \%$ of South Asians living in Bangladesh, India, Pakistan or Sri Lanka. In common with residents of many other lower-middle income countries (LMICs), the people of South Asia face multiple challenges, including high rates of both communicable and noncommunicable disease, fragile health and education systems, food and financial insecurity, and limited formal economic or social support.[1,2] Together, these characteristics are anticipated to make South Asian countries more vulnerable to major health and societal challenges such as COVID-19.

The first case of COVID-19 in South Asia was identified in January 2020, shortly before COVID19 was declared a pandemic by the WHO.[3] In response, Bangladesh, India, Pakistan and Sri Lanka implemented a range of highly restrictive national control measures to reduce the spread of COVID-19. This included closures of schools and non-essential workplaces, public transport bans, education campaigns for individual level behavioural interventions, isolation of symptomatic individuals, and contact tracing.[4,5] However, since then more than 7.4 million cases have been detected, with over 116,500 deaths (7th October 2020, https://www.worldometers.info/coronavirus/). The rate of new infections is still rapidly accelerating in India, which now has the second highest numbers of COVID-19 cases globally, indicating that the control measures may have been less effective than in other settings. Furthermore, there is increasing evidence that national lockdowns may have adverse effects for physical and mental health, children's education, behaviours relevant to chronic disease, as well as severe social and financial consequences.[6-10] There is an urgent need to understand how control measures can be further strengthened in South Asia, both to reduce the high rates of ongoing transmission, and to mitigate their unintended adverse consequences.

We interviewed 29,809 people participating in a long-term South Asian health surveillance study while restrictive national control measures were in place. We measured their knowledge of COVID19, adoption of preventive practices, and impact of COVID-19 on their physical and mental health, health-related behaviours, non-communicable disease care, social circumstances, and economic well-being. The ultimate goal of the study was to inform the design and implementation of further COVID-19 prevention and control programs in South Asia.

\section{Methods}

We used our network of health surveillance sites to evaluate the impact of COVID-19 on people living in five study regions: Bangladesh, South India, North India, Pakistan, and Sri Lanka. The surveillance sites include 52,813 South Asian men and women aged 18 years and above with comprehensive information on baseline health collected immediately prior to the COVID-19 pandemic (November 2018 to March 2020). We supplemented these baseline data with a telephone interview focussed on COVID-19, which was completed by 29,809 of the surveillance 
medRxiv preprint doi: https://doi.org/10.1101/2020.11.12.20229898; this version posted November 14, 2020. The copyright holder for this

study participants, during the national lockdowns implemented between March and July 2020. The study was approved by IRBs in each country, and consent was obtained from all participants for each round of data collection.

\section{Study settings and recruitment}

Recruitment to our health surveillance study took place at 93 surveillance sites (range 2 to 33 per study region, 74\% urban, Supplementary Table 1). Governmental census data and available household listings were used, together with house-house visits by research teams and local primary care workers, to identify (enumerate) the resident population. Resident adults (age 18 years and above) were invited to take part; exclusion criteria included current pregnancy, or serious illness expected to reduce life expectancy to less than 12 months. We worked closely with community senior members (e.g. teachers, employers, religious leaders) to support and facilitate engagement in the study. Explanations of the project's purpose were provided in writing and using videos, in relevant South Asian languages, supported by bilingual translators. Recruitment started in November 2018, and by March 2020 we had completed evaluation of 52,813 people (Bangladesh: 13,955; North India: 9,469; South India: 8,621; Pakistan: 5,833; Sri Lanka: 14,935).

\section{Baseline evaluation}

An interviewer-administered health and lifestyle questionnaire was used to collect information on behavioural risk factors (smoking, alcohol use, physical activity and consumption of fruits/vegetables), personal and family medical history, medications, and socio-economic status. Physical measurements included: a) Anthropometry (height, weight, waist and hip circumference and bio-impedance for body fat composition); b) Blood pressure by Omron digital device; c) Cardiac evaluation by 12 lead ECG to identify arrhythmia, left ventricular hypertrophy and previous myocardial infarction; d) Retinal photography for assessment of retinal disease, including hypertensive and diabetic retinopathy; and e). Respiratory evaluation by spirometry to assess for smoking/environment-related lung injury. Fasting glucose, and cholesterol were measured by point of care tests. Aliquots of blood and urine are stored for future molecular analyses. Equipment, protocols and training was standardised across sites.

\section{Follow-up COVID-19 questionnaire}

As part of an integrated effort, co-ordinated by the Wellcome Trust, we developed a questionnaire aimed at assessing (i) prevalence, knowledge and uptake of behaviours relevant to COVID-19; and, (ii) impact of COVID-19 on access to healthcare, behaviours linked to noncommunicable disease risk, social interactions and financial circumstances.[11] The questionnaire is available in full on our study website (www.ghru-southasia.org). We implemented the questionnaire by telephone during the national lockdown period, using a bespoke data capture tool based on KoBoToolbox, an open source data collection software. The study team attempted to 
medRxiv preprint doi: https://doi.org/10.1101/2020.11.12.20229898; this version posted November 14, 2020. The copyright holder for this preprint (which was not certified by peer review) is the author/funder, who has granted medRxiv a license to display the preprint in perpetuity.

All rights reserved. No reuse allowed without permission.

contact all 52,813 participants of our surveillance study. Training for questionnaire administration, and quality control of data collection were co-ordinated centrally.

\section{Statistical analysis}

Descriptive statistics are presented as mean (SD) or as \% for continuous and categorical variables, respectively. Participants were clustered geographically in surveillance sites. To account for heterogeneity in outcomes between sites due to unobserved contextual factors, we used a multilevel modelling regression approach with random effects (intercept) at the study site level to quantify the relationships between outcomes and potential predictors such as age, gender, education, prior income, and prior chronic condition. For analyses where the baseline (prepandemic) and follow-up (during the pandemic) data (e.g. behaviours linked with chronic disease risk, social and financial circumstances) were available, we examined the changes between the two time points. We conducted all analyses in STATA 15.

We analysed three groups of dependent variables: (i) COVID-19 burden, knowledge and preventive behaviours of COVID-19, (ii) Impact of COVID-19 on chronic disease and behaviours linked with chronic disease risk, and (iii) Impact of COVID-19 on social and financial circumstances. The prevalence of COVID-19 was estimated from reported symptoms, such as fever and cough; knowledge was tested for disease symptoms and transmission mechanism; and preventive behaviours included washing hands, wearing masks, and following social distancing. Impact on chronic disease included running out of routine medications, symptoms of psychosocial distress (e.g. anxiety and depression), and risk factors for chronic conditions (e.g. alcohol drinking, tobacco use, physical in activity, and unhealthy diet). Finally, impact on social and financial circumstances included household income, employment, and working hours.

\section{Results}

\section{Study population}

The baseline characteristics of all 52,813 participants in our surveillance study are summarised in Supplementary Table 2. Of these, 29,809 people successfully completed the COVID-19 questionnaire (Table 1, response rate 57\%), with little evidence for responder bias (Supplementary Figure 1). Participants were 61\% female, mean age 45 years, and living in Bangladesh $(8,807)$, North India $(6,152)$, South India $(3,834)$, Pakistan $(2,534)$ or Sri Lanka $(8,382)$. Almost half of participants had at least one chronic disease, including diabetes (16\%), hypertension (23\%) or obesity (16\%). Participants from South India and Sri Lanka were older, and had higher prevalence of diabetes, compared to other settings $(P<0.001)$. Cigarette smoking was highest, whilst education and indicators of socio-economic status were lowest, in Bangladesh and Pakistan $(P<0.001)$. The 'lockdown' control measures for each country during the survey period included major restrictions on movement outside the house, closure of schools and non-essential workplaces, and cancellation of public and religious events (Supplementary Table 3). 
medRxiv preprint doi: https://doi.org/10.1101/2020.11.12.20229898; this version posted November 14, 2020. The copyright holder for this preprint (which was not certified by peer review) is the author/funder, who has granted medRxiv a license to display the preprint in perpetuity.

COVID-19: burden, knowledge and preventive behaviours

Only $1.0 \%$ of people reported the combination of fever and cough during the study period, while $4.6 \%$ reported one or more of the recognised COVID-19 symptoms (Supplementary Table 4). Testing rates were consistently low, with just $0.9 \%$ of people reporting having had a swab test for COVID-19, including $<10 \%$ of people with suggestive symptoms. People with known chronic disease and with higher levels of education were $50 \%$ more likely to report suggestive symptoms, even after adjustment age, gender, education and income status $(P<0.01$, Supplementary Table 5).

Awareness of COVID-19 symptoms, and of the pathways to transmission, was moderate to high for the primary components (Supplementary Table 4). Fever and cough were recognised as COVID-19 symptoms by $90.1 \%$ and $79.5 \%$ of people respectively. However only $~ 50 \%$ of people recognised sore throat or breathlessness, and $<25 \%$ tiredness, myalgia or gastrointestinal disturbance, as being potential features of COVID-19. The proportions of people unaware that COVID-19 transmission is facilitated by contaminated surfaces, or by touching the face were high (45\% and 33\% respectively, Supplementary Table 4). Weaker knowledge of symptoms and transmission was more common in women, and also strongly associated with lower levels of education, lower income status and with increasing age (Supplementary Table 5; odds ratio for weaker knowledge: 2.2 (95\% Cl: $1.9-2.4)$ for age $>60$ years, and $2.7(95 \% \mathrm{Cl}: 2.4-3.3)$ for no formal education, compared to youngest age group and highest education group respectively (both $\mathrm{P}<0.001)$.

Knowledge of the personal preventive measures recommended to reduce transmission of COVID-19 was high in all settings (>95\% for most metrics, Supplementary Table 4). However, implementation of these measures in daily life was only moderate, representing both environmental and behavioural factors (Supplementary Table 4). Approximately $50 \%$ of people did not have access to hand sanitisers or tissues, and $70 \%$ had no access to gloves. Almost $40 \%$ of participants did not have access to clean running water in the home, and $59 \%$ did not have access to a room that could be used for self-isolation of people with known or suspected COVID-19. In addition, 10\% of people reported not wearing masks or following social distancing when outside, $25 \%$ went outside for non-essential reasons, and $75 \%$ of people continued to join meetings with people from across different households. Poorer access to and implementation of preventive measures was 2.9 (95\% Cl: 2.6-3.1) fold more common amongst women compared to men, and also more common amongst people from lower educational and financial backgrounds (all $\mathrm{P}<0.001$; Supplementary Table 5).

Impact of COVID-19 on chronic disease

Access to healthcare, including consultations, diagnostic tests and medications was compromised in all settings during the implementation of control measures (Figure 1). 
medRxiv preprint doi: https://doi.org/10.1101/2020.11.12.20229898; this version posted November 14, 2020. The copyright holder for this preprint (which was not certified by peer review) is the author/funder, who has granted medRxiv a license to display the preprint in perpetuity. All rights reserved. No reuse allowed without permission.

Approximately $24 \%$ of people were taking one or more regular medication, amongst whom $15 \%$ reported running out of supplies. Drugs for diabetes and hypertension were most commonly affected (61\% and $44 \%$ respectively). Restrictions to movement and financial pressures were identified as the primary reasons for impaired access to healthcare and medications (Supplementary Table 6). The impact on access to medication was greatest in the young (OR 1.62 [95\%Cl:1.17-2.64] for age 18-29 years, vs age $>60$ years, $\mathrm{P}<0.001$ ), in those with lower levels of income (OR 1.41 [95\% Cl: 1.14-1.84] for bottom vs top quintile of income, $\mathrm{P}<0.001$ ), and education (OR 1.48 [95\% Cl: 1.12-2.19] for no vs $13+$ years education, $\mathrm{P}<0.001)$, and 1.54 (95\%Cl: 1.12-1.95) higher amongst those with chronic disease (Supplementary Table 5).

COVID-19 also impacted behaviour patterns relevant to chronic disease (Figure 2). Physical activity patterns deteriorated during the pandemic, with a $32 \%$ (from 3.8 hours to 5.0 hours) increase in sedentary time, and there was a $10 \%$ (from $70 \%$ to $77.2 \%$ ) increase in the proportion of people reporting inadequate fruit and vegetable intake (both $\mathrm{P}<0.001$ ). Respondents reported weight loss in all study regions (average $3 \%$ from $62.5 \mathrm{~kg}$ to $62.1 \mathrm{~kg}, \mathrm{P}<0.001$ ). The deterioration in diet and physical activity was most marked in men (Supplementary Table 5). Lower levels of education were also associated with a greater negative impact of pandemic on physical activity, but a lesser effect on diet $(\mathrm{P}<0.001)$. Self-reported alcohol intake fell by $80 \%$ (from $11.0 \%$ to $2.2 \%$ ), and smoking rates by $41 \%$ (from $24.4 \%$ to $14.5 \%$ ) compared with pre-pandemic levels (both $\mathrm{P}<0.001)$. Continued tobacco and alcohol consumption were more than five-fold higher in men than women, while continued alcohol consumption was 1.7 fold $(95 \% \mathrm{Cl}: 1.17-2.24)$ more common in the most affluent quintile compared to the lowest quintile of income (both $P<0.001$ ). If the reduction in cigarette smoking can be maintained long term, this might reduce the future risk of CVD in the population by $13 \%$, and of lung cancer by $25 \%$ (Supplementary Table 7 ). Almost $40 \%$ of participants reported symptoms consistent with anxiety or depression (Figure 3). The prevalence of anxiety and depression was higher in people aged 30-49 years, amongst people with chronic disease, and in people with lower education and income (all $\mathrm{P}<0.05$, Supplementary Table 5).

\section{Impact of COVID-19 on social and financial circumstances}

The impact of COVID-19 control measures on employment and incomes was high. Compared to pre-pandemic, the proportion of respondents unemployed increased 3.5 fold from $9.3 \%$ to $39.4 \%$ $(P<0.001)$. Time in work decreased by $29 \%$ (from 41.1 to 29.2 hours) while household monthly income fell by $52 \%$ (from USD 240.0 to $114.4, \mathrm{P}<0.001$, Figure 4 ). The negative economic impact was greatest among younger participants, and amongst people with lower income and educational status at baseline (Supplementary Table 5). People with no formal education were 1.7 fold (95\%Cl: $1.53-1.97)$ more likely to report loss of employment, and 3.2 fold (95\%Cl: $2.82-3.63)$ more likely to report a fall in income, compared to the well-educated (both $\mathrm{P}<0.001$ ). Almost $4 \%$ of participants had to relocate during the lockdown; of these over $80 \%$ travelled over 100 miles to 
medRxiv preprint doi: https://doi.org/10.1101/2020.11.12.20229898; this version posted November 14, 2020. The copyright holder for this preprint (which was not certified by peer review) is the author/funder, who has granted medRxiv a license to display the preprint in perpetuity. All rights reserved. No reuse allowed without permission.

their new location. Social and financial support were heterogeneous across the regions (Supplementary Table 3). More than $50 \%$ of people in Sri Lanka reported receiving financial support (Supplementary Table 8). Support with supply of medications increased $45 \%$, whilst delivery of grocery shopping almost tripled, and access to subsidized food increased more than 6fold. Sri Lanka also had the lowest proportion of people reporting anxiety and depression. In other settings there was little evidence of participants receiving support from state or community sources (Supplementary Table 8).

\section{Discussion}

We assessed the knowledge, behaviours, health and socio-economic circumstances of 29,809 men and women, from 93 surveillance sites in four South Asian countries, during the national lockdowns that were implemented for COVID-19 between March and July 2020. Our findings provide a comprehensive assessment of the impact of COVID-19 and pandemic response measures on the health and wellbeing of South Asian communities. We found that many South Asians had poor access to essential resources for personal protection, and that uptake of recommended preventive measures was low, especially among people from modest educational and socio-economic backgrounds. We also found major negative impacts of COVID-19, and pandemic response measures, on chronic diseases, mental health and household finances. Access to healthcare for chronic diseases was compromised, including consultations, diagnostic tests and medications. Employment, income, and working hours fell substantially in all settings, and these were accompanied by a high prevalence of anxiety and depression. Younger people, and people from lower socio-economic groups were impacted the most. Although tobacco and alcohol consumption fell, so too did physical activity levels and fruit and vegetable intake. Our findings identify factors likely to have fuelled the continued progression of COVID-19 in South Asia. They also highlight the unanticipated, inequitable and unsustainable impacts of COVID-19, and pandemic responses, on chronic disease management, mental health and socio-economic circumstances. Our findings can inform the design of future policies aimed at preventing further spread of COVID-19 in South Asia, and mitigating adverse socio-economic impacts, especially on vulnerable population groups.

\section{COVID-19: burden, knowledge and preventive behaviours}

The prevalence of COVID-19 symptoms in the study population was low. Our results are consistent with an assessment of flu-like symptoms amongst healthcare workers in India during the same period,[12] but contrast with the findings of serology studies in Delhi and other urban South Asian settings, which indicate a high proportion of the populations tested may have been infected with COVID-19 during the lockdown.[13,14] These observations suggest that a high proportion of people in South Asia may be infected asymptomatically, in keeping with the younger age distribution of South Asian populations, compared to European or North American countries. A 
medRxiv preprint doi: https://doi.org/10.1101/2020.11.12.20229898; this version posted November 14, 2020. The copyright holder for this preprint (which was not certified by peer review) is the author/funder, who has granted medRxiv a license to display the preprint in perpetuity. All rights reserved. No reuse allowed without permission.

high proportion of individuals with asymptomatic COVID-19 represents an additional barrier to the identification and isolation of cases, underscoring the importance of molecular diagnostic assays. We note that COVID-19 testing was low during the assessment period. Although testing capacity has subsequently increased, there remain wide variations in availability, cost and uptake.

We found high knowledge for typical COVID-19 symptoms and transmission routes, positive attitudes towards preventive measures, and high adoption of hand washing with soap and water, consistent with previous reports.[15-17] We found incomplete knowledge for atypical COVID-19 symptoms and transmission routes, and important failures in the uptake of protective measures, in particular avoiding interactions between households and non-essential out-of-home activities. We found that uptake of protective measures is inversely related to education and socio-economic status, and also poorer amongst women and older people. A high proportion of respondents reported their households do not have access to running water, or suitable spaces for selfisolation. Our observations can contribute to explaining a continued sustained spread of the COVID-19 epidemic in some South Asian communities, and highlight the population groups that may benefit the most from further awareness raising measures and improved access to personal protection resources.

\section{COVID-19, non-communicable disease and healthy behaviours in South Asia}

Almost half of participants reported at least one non-communicable disease, most commonly diabetes or hypertension, conditions known to increase morbidity and mortality from COVID19.[18,19] In keeping with this, COVID-19 symptoms were more common amongst South Asians reporting a chronic condition. The well documented high burden of diabetes and hypertension in South Asians is contributing to the high impact of COVID-19 in this population.[20,21]

Our study design, which includes an assessment of key social and health metrics both prior to and during the pandemic, enables us to quantify the impact of COVID-19 on healthcare in different population sub-groups. We found adverse impacts on routine clinical care for people with chronic disease, reflecting a combination of reduced mobility, impaired supply of services, weakened financial circumstances and avoidance of healthcare settings. The impact was greatest amongst the more vulnerable in society, in particular those from lower socio-economic backgrounds. Our results expand the evidence base on the impacts of COVID-19 on access to healthcare in South Asia,[22-25] making a strong case for measures to protect routine health services, increase the use of digital platforms and provide medication support.[26]

Our baseline and follow-up data also enable an accurate assessment of the impact of the COVID-19 pandemic on health behaviours. We document a modest increase in inadequate fruit and vegetable consumption, and a more substantial increase in physical inactivity. Previous reports had shown increased carbohydrate consumption and snacking and reduced physical activity amongst Indians with type-2 diabetes during the pandemic.[27] However, there were also steep declines in smoking and alcohol consumption in most settings. If sustained, these might 
medRxiv preprint doi: https://doi.org/10.1101/2020.11.12.20229898; this version posted November 14, 2020. The copyright holder for this preprint (which was not certified by peer review) is the author/funder, who has granted medRxiv a license to display the preprint in perpetuity.

All rights reserved. No reuse allowed without permission.

translate into a substantial reduction in the risk of chronic diseases such as cardiovascular disease and lung cancer in the population. Understanding what drove the drop in tobacco and alcohol consumption could support the development of new policies to maintain those improvements in the future, but insights will also be needed to prevent further deterioration of diet and physical activity patterns while pandemic response measures last, and to promote a return to healthy lifestyles as measures are released.

We identified a high prevalence of anxiety and depression symptoms during the study period, highest in Bangladesh. Symptoms of psychosocial distress were more common in women, and amongst people with lower income and education. Our findings are consistent with others from Bangladesh, India and Pakistan,[28] and emphasise the potential negative impact of the COVID-19 pandemic on mental health in South Asia, a region that has some of the highest suicide rates globally.[29]

\section{Impact of COVID-19 on social and financial circumstances}

We found evidence of a high negative impact of the COVID-19 pandemic and response measures on social and economic circumstances in South Asia. We documented a substantial increase in unemployment, decreased work hours and a major reduction in household income. The adverse effects on financial circumstances were greatest for younger people, and those from less educated backgrounds. Governments throughout the world have identified the risks to economic wellbeing, and in many settings have implemented mitigation measures. Bangladesh re-opened the garment industry after just one month of lockdown, while Sri Lanka implemented a national financial support system and assistance with food supplies. However, these measures were insufficient to mitigate the tremendous impact of COVID-19 control measures on economic wellbeing. Our findings provide evidence of the scale of such impact for South Asian communities, and a strong case for robust social, organisational and fiscal measures to avoid long-lasting negative effects on the livelihoods of South Asian people.

\section{Strengths and limitations}

We have assessed the impact of COVID-19 on behaviours, health, and wellbeing in a large representative sample of South Asians from 93 sites across four countries. This brings precision and generalisability to our findings. We benefited from the existence of comprehensive data from participants collected just before the onset of the pandemic, enabling us to accurately assess people's changing situation. We used internationally validated questionnaires to ensure comparability with other studies. Although we recognise that the use of telephone surveys may introduce bias in recruitment, the characteristics of responders and non-responders were similar. Telephone surveys may also lead to response bias, however reliable baseline data collected prepandemic provided opportunities for validation in several instances. Our study was carried out at the height of the implementation of control measures, and restrictions have been eased in some 
medRxiv preprint doi: https://doi.org/10.1101/2020.11.12.20229898; this version posted November 14, 2020. The copyright holder for this preprint (which was not certified by peer review) is the author/funder, who has granted medRxiv a license to display the preprint in perpetuity.

All rights reserved. No reuse allowed without permission.

countries thereafter. However, our results provide objective evidence of the impact of control measures on the population, and can inform the design and implementation of further local or national restrictions, for COVID-19 or emerging viral pandemics.

\section{Conclusions}

Our study provides a comprehensive assessment of South Asian communities during the COVID-19 pandemic. We found a low uptake of recommended preventive measures among people from lower educational and socio-economic backgrounds, in women and in older age groups, and poor access to the resources needed for personal protection. We also found negative impacts of the pandemic on healthcare for chronic diseases, on diet and physical activity, employment and personal finances, and mental health. Impacts have been unequal, with younger people and people from lower socio-economic backgrounds impacted the most. Our results can contribute to explaining the continued progression of COVID-19 in South Asia, and provide a basis for the development of more effective, equitable and sustainable public health interventions for COVID-19 in the region. 
medRxiv preprint doi: https://doi.org/10.1101/2020.11.12.20229898; this version posted November 14, 2020. The copyright holder for this preprint (which was not certified by peer review) is the author/funder, who has granted medRxiv a license to display the preprint in perpetuity. All rights reserved. No reuse allowed without permission.

\section{Tables}

Table 1. Characteristics of the 29,809 study participants prior to COVID-19 pandemic

\section{Figures}

Figure 1. Impact of COVID-19 and control measures on access to healthcare for chronic disease.

Figure 2. Impact of COVID-19 and control measures on behaviours relevant to chronic disease.

Figure 3. Measures of mental health during the COVID-19 pandemic.

Figure 4. Impact of COVID-19 and control measures on employment and financial wellbeing. 
medRxiv preprint doi: https://doi.org/10.1101/2020.11.12.20229898; this version posted November 14, 2020. The copyright holder for this

\section{Acknowledgements}

This research was funded by the National Institute for Health Research (NIHR) (16/136/68) using UK aid from the UK Government to support global health research, and by Wellcome Trust (212945/Z/18/Z). The views expressed in this publication are those of the author(s) and not necessarily those of the NIHR or the UK Department of Health and Social Care.

\section{Conflict of interest}

None

\section{Contributions}

JCC, RMA, KIK, MKM, SJ, AK, PK, FS, DK conceived the study. RP, RBK, VM, SM, SB, MH, AAMH, MS, SS, ML AM, AT, SW, SMAS, ATR, SA, CKDS, VPR, LDS, MG, BK, IYG collected and cleaned the data. DK, RP, JCC, and FS conducted data analyses. JCC, MKM, DK, and FS drafted and ML, JSK provided inputs to the manuscript. All authors approved the final version of the manuscript.

\section{The NIHR Global Health Research Unit for Diabetes and Cardiovascular Disease}

RM Anjana, Mohan Diabetes Research Foundation, Chennai, India; John C Chambers, Imperial College London, UK; Sophie Day, Imperial College London, UK; Gary Frost, Imperial College London, UK; Sujeet Jha, Max Healthcare, Delhi, India; Prasad Katulanda, University of Colombo, Sri Lanka; Khadija I Khawaja, Services Institute of Medical Sciences, Lahore, Pakistan; Jaspal S Kooner, Imperial College London, UK; Marie Loh, Imperial College London, UK; Marisa Miraldo, Imperial College London, UK; Malay K Mridha, BRAC University, Dhaka, Bangladesh; Nicholas Oliver, Imperial College London, UK; Malibika Sarker, BRAC University, Dhaka, Bangladesh; Jonathan Valabhji, Imperial College London, UK. 
medRxiv preprint doi: https://doi.org/10.1101/2020.11.12.20229898; this version posted November 14, 2020. The copyright holder for this preprint (which was not certified by peer review) is the author/funder, who has granted medRxiv a license to display the preprint in perpetuity. All rights reserved. No reuse allowed without permission.

\section{References}

1. Laxminarayan, R., Kakkar, M., Horby, P., Malavige, G. N., \& Basnyat, B. (2017). Emerging and re-emerging infectious disease threats in South Asia: status, vulnerability, preparedness, and outlook. BMJ, 357, j1447.

2. Misra, A., Tandon, N., Ebrahim, S., et al. (2017). Diabetes, cardiovascular disease, and chronic kidney disease in South Asia: current status and future directions. BMJ, 357, j1420.

3. Reuters (2020) Sri Lanka confirms first case of coronavirus: health official. 27 January 2020. Online: https://www.reuters.com/article/us-health-china-sri-lanka/sri-lanka-confirms-first-caseof-coronavirus-health-official-idUSKBN1ZQ1WF

4. Agoramoorthy, G. (2020). "India fights hard to neutralize the spread of COVID-19." Infect Control Hosp Epidemiol: 1.

5. Anwar, S., M. Nasrullah and M. J. Hosen (2020). "COVID-19 and Bangladesh: Challenges and How to Address Them." Front Public Health 8: 154.

6. Rossi, R., Socci, V., Talevi, D., et al. (2020). COVID-19 pandemic and lockdown measures impact on mental health among the general population in Italy. Frontiers in Psychiatry, 11.

7. Alvi, M. and M. Gupta (2020). "Learning in times of lockdown: how Covid-19 is affecting education and food security in India." Food Secur: 1-4.

8. Pieh, C., Budimir, S., \& Probst, T. (2020). The effect of age, gender, income, work, and physical activity on mental health during coronavirus disease (COVID-19) lockdown in Austria. Journal of psychosomatic research, 136, 110186.

9. Verma, A., Rajput, R., Verma, S., Balania, V. K., \& Jangra, B. (2020). Impact of lockdown in COVID 19 on glycemic control in patients with type 1 Diabetes Mellitus. Diabetes \& Metabolic Syndrome: Clinical Research \& Reviews, 14(5), 1213-1216.

10. Ceballos, F., Kannan, S., \& Kramer, B. (2020). Impacts of a national lockdown on smallholder farmers' income and food security: Empirical evidence from two states in India. World Development, 136, 105069.

11. De Silva M, Herbst K, Galobardes B, et al. \& LMIC Working Group (2020). LMIC COVID-19 Core Questionnaire. https://ihccglobal.org/covidsurvey/

12. Jha, S., A. Soni, S. Siddiqui, N. Batra, N. et al. (2020). "Prevalence of Flu-like Symptoms and COVID-19 in Healthcare Workers from India." J Assoc Physicians India 68(7): 27-29.

13. Pollán, M., Pérez-Gómez, B., Pastor-Barriuso, R., et al. (2020). Prevalence of SARS-CoV-2 in Spain (ENE-COVID): a nationwide, population-based seroepidemiological study. The Lancet, 396(10250), 535-544.

14. Stringhini, S., Wisniak, A., Piumatti, G., et al. (2020). Seroprevalence of anti-SARS-CoV-2 IgG antibodies in Geneva, Switzerland (SEROCoV-POP): a population-based study. The Lancet. 
medRxiv preprint doi: https://doi.org/10.1101/2020.11.12.20229898; this version posted November 14, 2020. The copyright holder for this preprint (which was not certified by peer review) is the author/funder, who has granted medRxiv a license to display the preprint in perpetuity. All rights reserved. No reuse allowed without permission.

15. Dkhar, S. A., R. Quansar, S. M. Saleem and S. M. S. Khan (2020). "Knowledge, attitude, and practices related to COVID-19 pandemic among social media users in J\&K, India." Indian J Public Health 64(Supplement): S205-S210.

16. Afzal, M. S., A. Khan, U. U. R. Qureshi, et al. (2020). "Community-Based Assessment of Knowledge, Attitude, Practices and Risk Factors Regarding COVID-19 Among Pakistanis Residents During a Recent Outbreak: A Cross-Sectional Survey." J Community Health.

17. Gambhir, R. S., Dhaliwal, J. S., Aggarwal, A., Anand, S., Anand, V., \& Bhangu, A. K. (2020). Covid-19: a survey on knowledge, awareness and hygiene practices among dental health professionals in an Indian scenario. Rocz Panstw Zakl Hig 71(2): 223-229.

18. Basu, S. (2020). "Non-communicable disease management in vulnerable patients during Covid-19." Indian J Med Ethics V(2): 103-105.

19. Ofori-Asenso, R., O. Ogundipe, A. A. Agyeman, K. L. et al. (2020). "Cancer is associated with severe disease in COVID-19 patients: a systematic review and meta-analysis." Ecancermedicalscience 14: 1047.

20. Anjana, R. M., Deepa, M., Pradeepa, R. et al. (2017). Prevalence of diabetes and prediabetes in 15 states of India: results from the ICMR-INDIAB population-based cross-sectional study. The Lancet Diabetes \& Endocrinology, 5(8), 585-596.

21. Chambers, J. C., Loh, M., Lehne, B. et al. (2015). Epigenome-wide association of DNA methylation markers in peripheral blood from Indian Asians and Europeans with incident type 2 diabetes: a nested case-control study. The Lancet Diabetes \& Endocrinology, 3(7), 526-534.

22. Deshmukh, S., S. Naik, B. Zade, R. et al. (2020). "Impact of the pandemic on cancer care: Lessons learnt from a rural cancer center in the first 3 months." J Surg Oncol.

23. Khader, M. A., T. Jabeen and R. Namoju (2020). "A cross sectional study reveals severe disruption in glycemic control in people with diabetes during and after lockdown in India." Diabetes Metab Syndr 14(6): 1579-1584.

24. Khare, J. and S. Jindal (2020). "Observational study on Effect of Lock Down due to COVID 19 on glycemic control in patients with Diabetes: Experience from Central India." Diabetes Metab Syndr 14(6): 1571-1574.

25. Nachimuthu, S., R. Vijayalakshmi, M. Sudha and V. Viswanathan (2020). "Coping with diabetes during the COVID - 19 lockdown in India: Results of an online pilot survey." Diabetes Metab Syndr 14(4): 579-582.

26. Joshi, R., S. Atal, Z. Fatima, S. Balakrishnan, S. Sharma and A. Joshi (2020). "Diabetes care during COVID-19 lockdown at a tertiary care centre in India." Diabetes Res Clin Pract 166: 108316.

27. Ghosh, A., B. Arora, R. Gupta, S. Anoop and A. Misra (2020). "Effects of nationwide lockdown during COVID-19 epidemic on lifestyle and other medical issues of patients with type 2 diabetes in north India." Diabetes Metab Syndr 14(5): 917-920. 
medRxiv preprint doi: https://doi.org/10.1101/2020.11.12.20229898; this version posted November 14, 2020. The copyright holder for this preprint (which was not certified by peer review) is the author/funder, who has granted medRxiv a license to display the preprint in perpetuity. All rights reserved. No reuse allowed without permission.

28. Yeasmin, S., Banik, R., Hossain, S., et al. (2020). Impact of COVID-19 pandemic on the mental health of children in Bangladesh: A cross-sectional study. Children and youth services review, $117,105277$.

29. Jordans, M. J., Kaufman, A., Brenman, N. F., et al. (2014). Suicide in South Asia: a scoping review. BMC psychiatry, 14(1), 358. 
medRxiv preprint doi: https://doi.org/10.1101/2020.11.12.20229898; this version posted November 14, 2020. The copyright holder for this preprint (which was not certified by peer review) is the author/funder, who has granted medRxiv a license to display the preprint in perpetuity. All rights reserved. No reuse allowed without permission.

Main tables/figures

Table $1 \quad$ Baseline characteristics of study participants by region (29809)

Figure 1 Impact on chronic disease

Figure 2 Impact on behaviour

Figure 3 Impact on mental health

Figure 4 Impact on economics

Supplementary tables/figures

ST1 Number of sites per region

ST2 Characteristics for the 52,813

ST3 Control measures in place

ST4 Prevalence of symptoms suggestive for COVID-19 by region

ST5 Lockdown impacts on socioeconomic and health status

ST6 COVID-19 and access to medications

ST7 Smoking cessation and risks for CVD and lung cancer

ST8 COVID-19 and social and financial support

Fig1 Forest plot showing ORs of responder bias 
medRxiv preprint doi: https://doi.org/10.1101/2020.11.12.20229898; this version posted November 14, 2020. The copyright holder for this preprint (which was not certified by peer review) is the author/funder, who has granted medRxiv a license to display the preprint in perpetuity.

All rights reserved. No reuse allowed without permission.

Table 1: Characteristics of the 29,809 study participants prior to COVID-19 pandemic

\begin{tabular}{|c|c|c|c|c|c|c|c|c|c|c|c|c|}
\hline & \multicolumn{2}{|c|}{ Total } & \multicolumn{2}{|c|}{ Bangladesh } & \multicolumn{2}{|c|}{ North India } & \multicolumn{2}{|c|}{ South India } & \multicolumn{2}{|c|}{ Pakistan } & \multicolumn{2}{|c|}{ Sri Lanka } \\
\hline & $\mathrm{n} /$ mean & $\% / S D$ & $\mathrm{n} /$ mean & $\% / S D$ & $\mathrm{n} /$ mean & $\% / S D$ & $\mathrm{n} / \mathrm{mean}$ & $\% / S D$ & $\mathrm{n} /$ mean & $\% / S D$ & $\mathrm{n} / \mathrm{mean}$ & $\% / S D$ \\
\hline \multicolumn{13}{|l|}{ (a) Basic characteristics } \\
\hline Female (n, \%) & 18111 & $60.8 \%$ & 4622 & $52.5 \%$ & 3745 & $60.9 \%$ & 2330 & $59.2 \%$ & 1644 & $64.9 \%$ & 5770 & $68.8 \%$ \\
\hline Age (year, SD) & 45.1 & 14.1 & 42.8 & 13.6 & 41.6 & 13.6 & 48.9 & 12.9 & 42.6 & 12.6 & 49.1 & 14.5 \\
\hline Household income (USD, SD) & 240.0 & 203.9 & 219.2 & 188.7 & 307.9 & 247.9 & 234.0 & 179.4 & 176.6 & 184.7 & 235.3 & 187.7 \\
\hline Education (year, SD) & 7.3 & 4.7 & 5.7 & 4.7 & 7.1 & 4.6 & 7.1 & 3.9 & 3.7 & 4.9 & 10.4 & 2.8 \\
\hline \multicolumn{13}{|l|}{ Employment } \\
\hline Government employee (n, \%) & 1064 & $3.6 \%$ & 156 & $1.8 \%$ & 83 & $1.4 \%$ & 95 & $2.4 \%$ & 213 & $8.5 \%$ & 517 & $6.2 \%$ \\
\hline Non-government employee (n, \%) & 4792 & $16.3 \%$ & 606 & $6.9 \%$ & 1724 & $29.0 \%$ & 1024 & $26.1 \%$ & 163 & $6.5 \%$ & 1275 & $15.4 \%$ \\
\hline Self-employed $(n, \%)$ & 7624 & $25.9 \%$ & 3455 & $39.4 \%$ & 848 & $14.3 \%$ & 1300 & $33.2 \%$ & 344 & $13.7 \%$ & 1677 & $20.2 \%$ \\
\hline Non-paid (n, \%) & 60 & $0.2 \%$ & 3 & $0.03 \%$ & 20 & $0.3 \%$ & 17 & $0.4 \%$ & 6 & $0.2 \%$ & 14 & $0.2 \%$ \\
\hline Student $(\mathrm{n}, \%)$ & 729 & $2.5 \%$ & 157 & $1.8 \%$ & 274 & $4.6 \%$ & 23 & $0.6 \%$ & 61 & $2.4 \%$ & 214 & $2.6 \%$ \\
\hline Homemaker (n, \%) & 10953 & $37.2 \%$ & 3983 & $45.4 \%$ & 2551 & $42.9 \%$ & 1164 & $29.7 \%$ & 1525 & $60.9 \%$ & 1730 & $20.8 \%$ \\
\hline Retired (n, \%) & 1116 & $3.8 \%$ & 179 & $2.0 \%$ & 147 & $2.5 \%$ & 150 & $3.8 \%$ & 41 & $1.6 \%$ & 599 & $7.2 \%$ \\
\hline Unemployed (able to work) (n, \%) & 2142 & $7.3 \%$ & 72 & $0.8 \%$ & 163 & $2.7 \%$ & 117 & $3.0 \%$ & 115 & $4.6 \%$ & 1675 & $20.2 \%$ \\
\hline Unemployed (unable to work) (n, \%) & 970 & $3.3 \%$ & 164 & $1.9 \%$ & 138 & $2.3 \%$ & 32 & $0.8 \%$ & 36 & $1.4 \%$ & 600 & $7.2 \%$ \\
\hline \multicolumn{13}{|l|}{ (b) Chronic diseases/clinical risk factors } \\
\hline At least one $(\mathrm{n}, \%)$ & 13840 & $46.4 \%$ & 3202 & $36.4 \%$ & 2652 & $43.1 \%$ & 2019 & $51.3 \%$ & 1392 & $54.9 \%$ & 4575 & $54.6 \%$ \\
\hline Raised blood pressure (n, \%) & 6621 & $22.6 \%$ & 1841 & $21.2 \%$ & 1272 & $21.4 \%$ & 816 & $20.8 \%$ & 710 & $28.4 \%$ & 1982 & $23.9 \%$ \\
\hline Obese (n, \%) & 4844 & $16.3 \%$ & 647 & $7.3 \%$ & 1035 & $16.8 \%$ & 925 & $23.5 \%$ & 874 & $34.5 \%$ & 1363 & $16.3 \%$ \\
\hline Diabetes mellitus (n, \%) & 4642 & $15.8 \%$ & 783 & $8.9 \%$ & 741 & $12.5 \%$ & 974 & $24.8 \%$ & 414 & $16.5 \%$ & 1730 & $20.8 \%$ \\
\hline Raised cholesterol (n, \%) & 3029 & $10.4 \%$ & 364 & $4.3 \%$ & 333 & $5.6 \%$ & 247 & $6.3 \%$ & 107 & $4.3 \%$ & 1978 & $23.8 \%$ \\
\hline $\operatorname{CVD}(\mathrm{n}, \%)$ & 2697 & $9.2 \%$ & 587 & $6.7 \%$ & 478 & $8.0 \%$ & 123 & $3.1 \%$ & 109 & $4.4 \%$ & 1400 & $16.9 \%$ \\
\hline Lung $(\mathrm{n}, \%)$ & 1470 & $5.0 \%$ & 581 & $6.6 \%$ & 278 & $4.7 \%$ & 18 & $0.5 \%$ & 28 & $1.1 \%$ & 565 & $6.8 \%$ \\
\hline Renal (n, \%) & 174 & $0.6 \%$ & 86 & $1.0 \%$ & 29 & $0.5 \%$ & 20 & $0.5 \%$ & 8 & $0.3 \%$ & 31 & $0.4 \%$ \\
\hline Cancer $(\mathrm{n}, \%)$ & 96 & $0.3 \%$ & 16 & $0.2 \%$ & 31 & $0.5 \%$ & 2 & $0.1 \%$ & 2 & $0.1 \%$ & 45 & $0.5 \%$ \\
\hline \multicolumn{13}{|l|}{ (c) Behavior/risk factors } \\
\hline Current smoking $(\mathrm{n}, \%)$ & 7185 & $24.4 \%$ & 4457 & $50.8 \%$ & 1245 & $20.9 \%$ & 281 & $7.2 \%$ & 219 & $8.7 \%$ & 983 & $11.8 \%$ \\
\hline Current drinking (n, \%) & 3247 & $11.0 \%$ & 231 & $2.6 \%$ & 1128 & $19.0 \%$ & 440 & $11.2 \%$ & 2 & $0.1 \%$ & 1446 & $17.4 \%$ \\
\hline Body mass index $(\mathrm{kg} / \mathrm{m} 2, \mathrm{SD})$ & 25.4 & 5.7 & 23.6 & 5.1 & 25.5 & 5.4 & 27.1 & 6.6 & 28.1 & 6.5 & 25.6 & 5.2 \\
\hline Systolic BP $(\mathrm{mmHg}, \mathrm{SD})$ & 121.3 & 19.8 & 117.4 & 19.7 & 116.2 & 18.0 & 130.4 & 20.1 & 125.3 & 18.1 & 123.7 & 19.6 \\
\hline Diastolic BP (mmHg, SD) & 76.1 & 12.2 & 73.4 & 11.8 & 73.5 & 11.1 & 83.7 & 12.1 & 82.2 & 11.7 & 75.4 & 11.4 \\
\hline $\mathrm{N}, \%$ & 29809 & $100 \%$ & 8807 & $29.5 \%$ & 6152 & $20.6 \%$ & 3934 & $13.2 \%$ & 2534 & $8.5 \%$ & 8382 & $28.1 \%$ \\
\hline
\end{tabular}

Note: $\mathrm{N}=$ Sample, $\mathrm{SD}=$ Standard deviation, USD=United States Dollar, $\mathrm{CVD}=$ Cardiovascular diseases, $\mathrm{BP}=\mathrm{Blood}$ pressure, $\mathrm{mmHg}=$ millimeters of mercury 
medRxiv preprint doi: https://doi.org/10.1101/2020.11.12.20229898; this version posted November $14,2020$. The copyright holder for this preprint (which was not certified by peer review) is the author/funder, who has granted medRxiv a license to display the preprint in perpetuity.

All rights reserved. No reuse allowed without permission.

Figure 1. Impact on chronic diseases

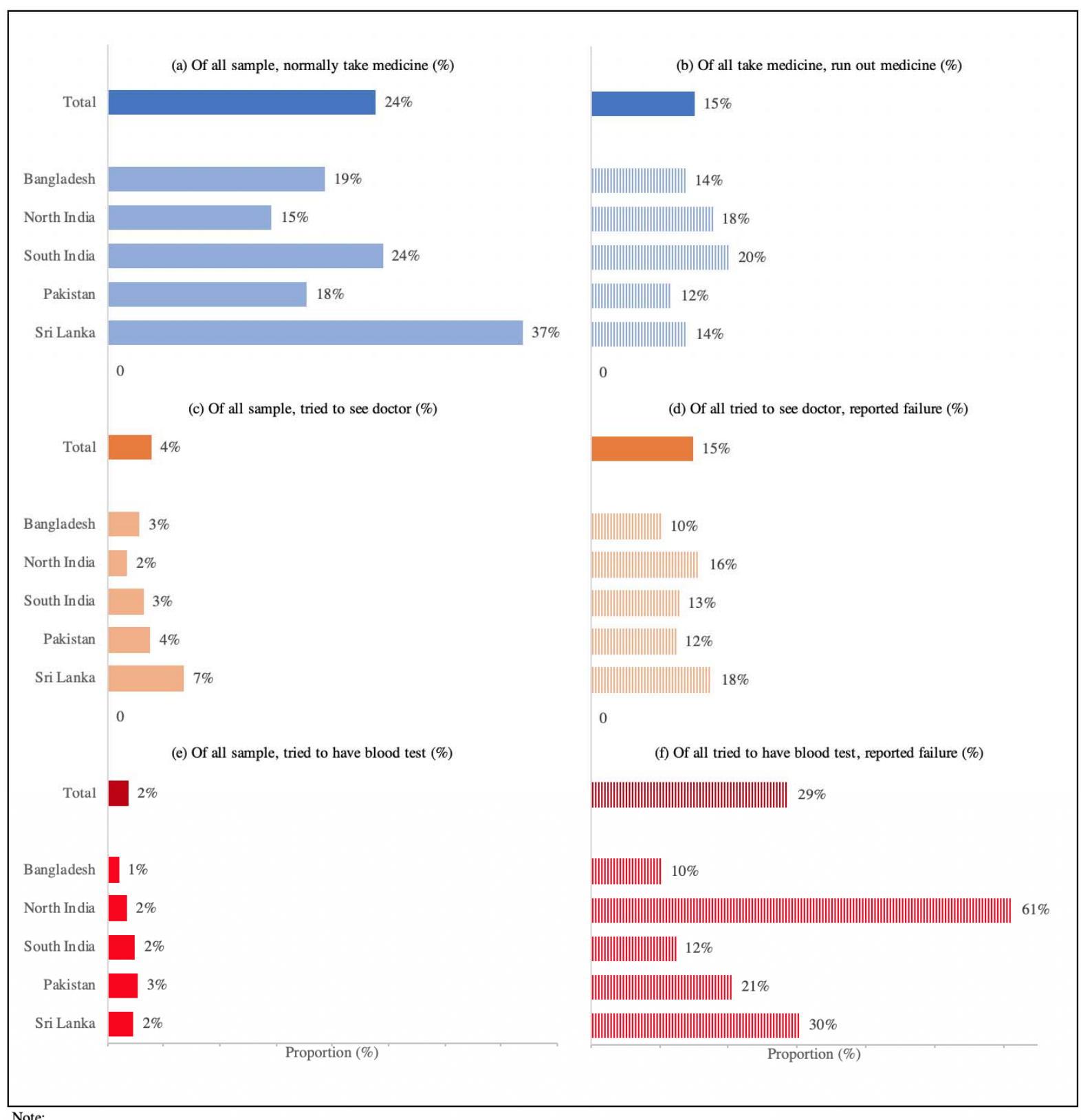

Note:

In panels a, c, d, the total sample is $\mathrm{n}=29,809$; in panels $\mathrm{b}, \mathrm{d}, \mathrm{f}$, the total samples are 7110,1156 , and 552 respectively.

In other words, panel $\mathrm{b}$ is a fraction of panel a; panel $\mathrm{d}$ is a fraction of panel $\mathrm{c}$, and panel $\mathrm{f}$ is a fraction of panel $\mathrm{e}$.

All values are after or during lockdown. 
medRxiv preprint doi: https://doi.org/10.1101/2020.11.12.20229898; this version posted November 14, 2020. The copyright holder for this preprint (which was not certified by peer review) is the author/funder, who has granted medRxiv a license to display the preprint in perpetuity.

All rights reserved. No reuse allowed without permission.

Figure 2. Impact on behavior relevant to chronic disease
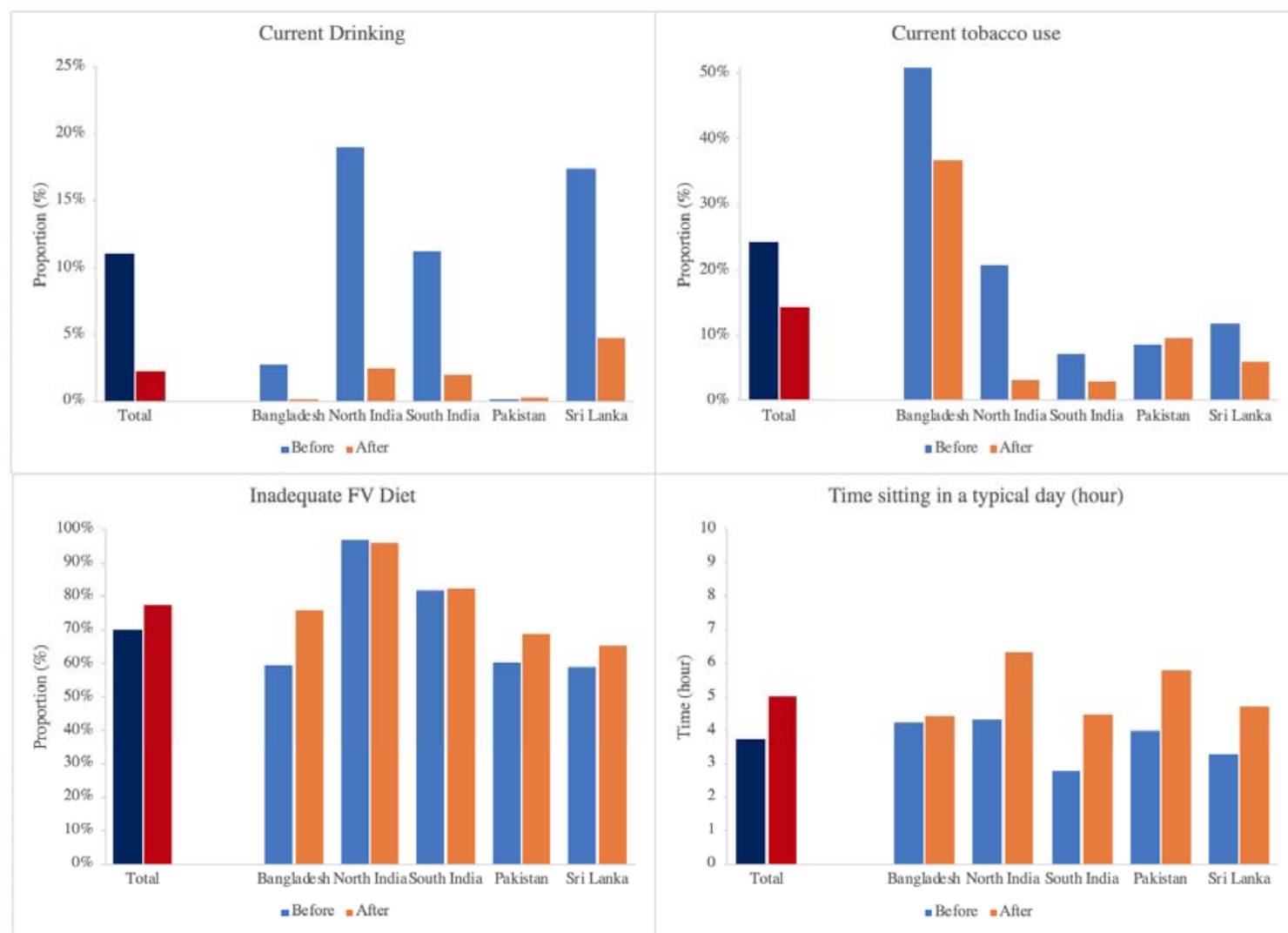

Note:

$\mathrm{FV}=$ Fruit and vegetable. Currently drinking $=1$ if answered yes to

Currently drinking=1 if answered yes to the question "Do you drink alcohol?"

Current tobacco use=1 if answered yes to either or both questions "Do you currently smoke any tobacco products daily, such as cigarettes, cigars or pipes?" and "Do you currently use any snuff, chewing tobacco or betel?"

Inadequate $\mathrm{FV}$ diet $=1$ if total serving of fruit or vegetable is less than 5 servings in the last week.

Time sitting in a typical day = How much time a person usually spends sitting or reclining on a typical day.

P-values for each of the four total comparisons (dark blue and dark red) $<0.001$ 
medRxiv preprint doi: https://doi.org/10.1101/2020.11.12.20229898; this version posted November 14, 2020. The copyright holder for this preprint (which was not certified by peer review) is the author/funder, who has granted medRxiv a license to display the preprint in perpetuity.

All rights reserved. No reuse allowed without permission.

Figure 3. Impact on mental health

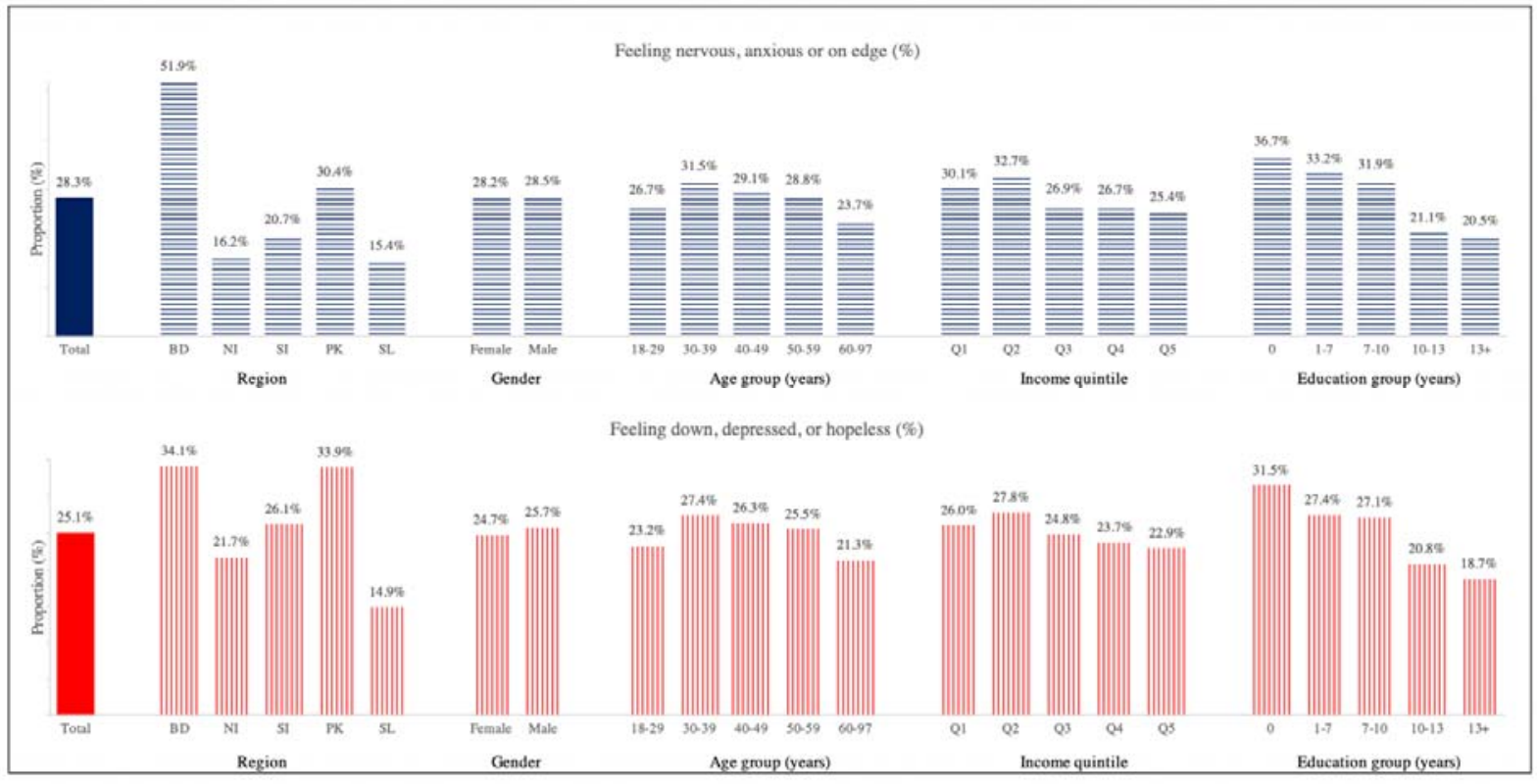

Note: BD=Bangladesh, $\mathrm{Nl}=$ North India, $\mathrm{SI}=$ South India, PK=Pakistan, $\mathrm{SL}=$ Sri Lanka. All values are after lockdown. 
medRxiv preprint doi: https://doi.org/10.1101/2020.11.12.20229898; this version posted November 14, 2020. The copyright holder for this preprint (which was not certified by peer review) is the author/funder, who has granted medRxiv a license to display the preprint in perpetuity.

All rights reserved. No reuse allowed without permission.

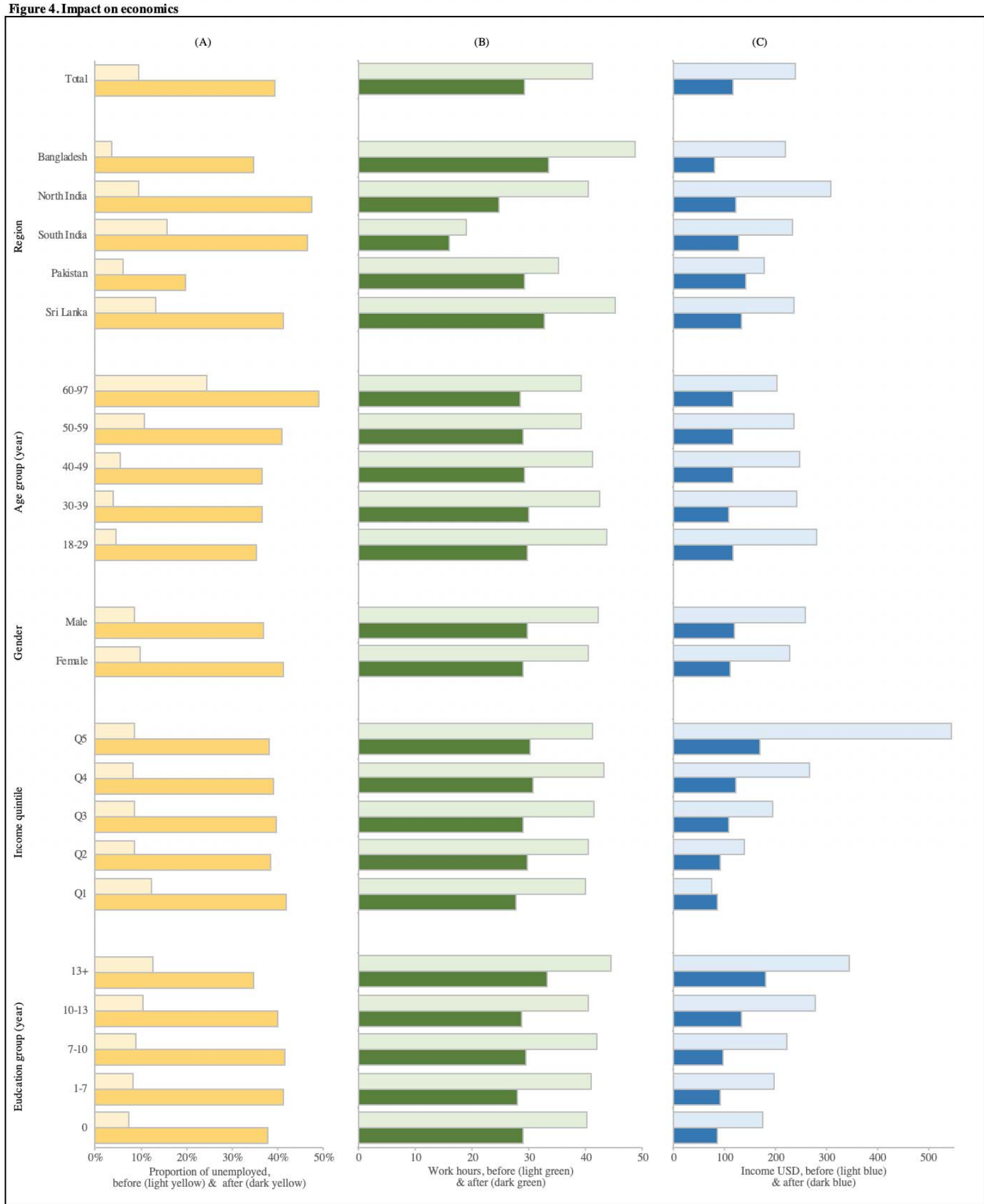

Note:

In panel A, light and dark yellow are the proportions of unemployment before and after lockdown; In panel B, light and dark green are the working hours before and after lockdown; In panel $\mathrm{C}$, light and dark blue are the income in USD before and after lockdown

P-values for each of the three total comparisons (light and dark yellow/green/blue) $<0.00$ 
medRxiv preprint doi: https://doi.org/10.1101/2020.11.12.20229898; this version posted November 14, 2020. The copyright holder for this preprint (which was not certified by peer review) is the author/funder, who has granted medRxiv a license to display the preprint in perpetuity. All rights reserved. No reuse allowed without permission.

\section{Supplementary Table 1: Surveilance sites by region}

\begin{tabular}{lccccc}
\hline Region & Number of site & Urban site & Target N & Interviewed & Response rate \\
\hline Bangladesh & 15 & $6(40 \%)$ & 13955 & 8819 & $63.20 \%$ \\
North India & 2 & $2(100 \%)$ & 9469 & 6170 & $65.20 \%$ \\
South India & 33 & $33(100 \%)$ & 8621 & 3944 & $45.70 \%$ \\
Pakistan & 15 & $12(80 \%)$ & 5833 & 2548 & $43.70 \%$ \\
Sri Lanka & 28 & $21(75 \%)$ & 14935 & 8409 & $56.30 \%$ \\
TOTAL & 93 & $74(80 \%)$ & 52813 & 29890 & $56.60 \%$ \\
\hline
\end{tabular}


medRxiv preprint doi: https://doi.org/10.1101/2020.11.12.20229898; this version posted November 14, 2020. The copyright holder for this preprint (which was not certified by peer review) is the author/funder, who has granted medRxiv a license to display the preprint in perpetuity.

All rights reserved. No reuse allowed without permission.

Supplementary Table 2: Characteristics of all surveilance participants (panel a) and responder bias (panel b)

\begin{tabular}{|c|c|c|c|c|c|c|c|}
\hline & \multicolumn{2}{|c|}{ (a) Total baseline } & \multicolumn{2}{|c|}{ (b) Response status } & \multirow[t]{2}{*}{ Crude P } & \multirow{2}{*}{$\begin{array}{c}\text { Difference / OR } \\
\text { (LCI to UCI) }\end{array}$} & \multirow[t]{2}{*}{ Adjusted P } \\
\hline & $\mathrm{n} / \mathrm{mean}$ & $\% / \mathrm{SD}$ & Non-responder & Responder & & & \\
\hline & [1] & & [2] & [3] & [4] & {$[5]=[3 / 2]$} & [6] \\
\hline $\mathrm{N}$ & 52,813 & & 22912 & 29864 & & & \\
\hline Female & 33,082 & $62.6 \%$ & $65.20 \%$ & $60.80 \%$ & $<0.001$ & 0.84 (0.81 to 0.87$)$ & $<0.001$ \\
\hline Age (years) & 46.0 & 14.3 & $46.6(14.5)$ & $45.1(14.1)$ & $<0.001$ & $-1.54(-1.8$ to -1.28$)$ & $<0.001$ \\
\hline \multicolumn{8}{|l|}{ Age categories } \\
\hline$<30$ yrs old & 7,055 & $13.4 \%$ & $13.90 \%$ & $16.70 \%$ & $<0.001$ & $1.15(1.10$ to 1.21$)$ & $<0.001$ \\
\hline $30-50$ yrs old & 24,584 & $46.6 \%$ & $45.90 \%$ & $48.40 \%$ & & $1.10(1.06$ to 1.14$)$ & $<0.001$ \\
\hline$>50$ yrs old & 21,173 & $40.1 \%$ & $40.20 \%$ & $34.90 \%$ & & 0.83 (0.80 to 0.87$)$ & $<0.001$ \\
\hline Years at school (years) & 6.9 & 4.7 & $6.4(4.8)$ & $7.3(4.7)$ & $<0.001$ & 0.48 (0.40 to 0.55$)$ & $<0.001$ \\
\hline \multicolumn{8}{|l|}{ Education achieved } \\
\hline Primary school or below & 21,055 & $52.2 \%$ & $53.50 \%$ & $51.30 \%$ & $<0.001$ & $0.82(0.78$ to 0.85$)$ & $<0.001$ \\
\hline Secondary school & 9,104 & $22.6 \%$ & $37.80 \%$ & $39.70 \%$ & & $1.19(1.14$ to 1.24$)$ & $<0.001$ \\
\hline Postgraduate & 10,171 & $25.2 \%$ & $8.70 \%$ & $9.00 \%$ & & 1.11 (1.03 to 1.19$)$ & 0.007 \\
\hline \multicolumn{8}{|l|}{ Marital Status } \\
\hline Never Married & 3,578 & $6.9 \%$ & $6.40 \%$ & $7.30 \%$ & $<0.001$ & 1.04 (0.96 to 1.13$)$ & 0.37 \\
\hline Currently married & 43,823 & $84.5 \%$ & $83.40 \%$ & $85.40 \%$ & & $1.15(1.09$ to 1.21$)$ & $<0.001$ \\
\hline Widowed & 3,869 & $7.5 \%$ & $8.90 \%$ & $6.40 \%$ & & 0.89 (0.82 to 0.96$)$ & 0.001 \\
\hline Separated or Divorced & 576 & $1.1 \%$ & $1.30 \%$ & $1.00 \%$ & & 0.78 (0.66 to 0.92$)$ & 0.003 \\
\hline \multicolumn{8}{|l|}{ Occupation } \\
\hline Government employee & 1,800 & $3.5 \%$ & $3.30 \%$ & $3.60 \%$ & $<0.001$ & $1.19(1.08$ to 1.31$)$ & $<0.001$ \\
\hline Non-government employee & 8,218 & $15.9 \%$ & $15.30 \%$ & $16.30 \%$ & & $1.01(0.96$ to 1.06$)$ & 0.75 \\
\hline Self-employed & 13,314 & $25.7 \%$ & $25.40 \%$ & $25.90 \%$ & & 0.93 (0.89 to 0.98$)$ & 0.003 \\
\hline Non-paid & 111 & $0.2 \%$ & $0.20 \%$ & $0.20 \%$ & & $1.02(0.69$ to 1.50$)$ & 0.91 \\
\hline Student & 1,127 & $2.2 \%$ & $1.80 \%$ & $2.50 \%$ & & $1.26(1.08$ to 1.46$)$ & 0.003 \\
\hline Homemaker & 19,744 & $38.1 \%$ & $39.30 \%$ & $37.20 \%$ & & $1.03(0.98$ to 1.08$)$ & 0.27 \\
\hline Retired & 1,909 & $3.7 \%$ & $3.50 \%$ & $3.80 \%$ & & 1.30 (1.18 to 1.44$)$ & $<0.001$ \\
\hline Unemployed (able to work) & 3,738 & $7.2 \%$ & $7.10 \%$ & $7.30 \%$ & & 1.07 (1.00 to 1.15$)$ & 0.06 \\
\hline Unemployed (unable to work) & 1,890 & $3.7 \%$ & $4.10 \%$ & $3.30 \%$ & & 0.93 (0.84 to 1.03$)$ & 0.15 \\
\hline Hypertension history & $11,521.0$ & $22.3 \%$ & $22.60 \%$ & $22.00 \%$ & 0.13 & $1.11(1.06$ to 1.16$)$ & $<0.001$ \\
\hline Diabetes history & $8,224.0$ & $15.9 \%$ & $16.40 \%$ & $15.50 \%$ & 0.004 & 1.13 (1.08 to 1.19$)$ & $<0.001$ \\
\hline Heart attack history & $1,397.0$ & $2.7 \%$ & $2.80 \%$ & $2.60 \%$ & 0.37 & 1.01 (0.90 to 1.12$)$ & 0.93 \\
\hline Body mass index $(\mathrm{kg} / \mathrm{m} 2)$ & 25.4 & 5.8 & $25.4(6.0)$ & $25.4(5.7)$ & 0.64 & $0.46(0.36$ to 0.56$)$ & $<0.001$ \\
\hline Waist (cm) & 85.7 & 13.0 & $85.7(13.5)$ & $85.6(12.6)$ & 0.34 & $1.05(0.84$ to 1.27$)$ & $<0.001$ \\
\hline Systolic BP (mmHg) & 130.9 & 1961.6 & $123.5(21.0)$ & $121.3(19.9)$ & $<0.001$ & $-0.02(-0.35$ to 0.32$)$ & 0.91 \\
\hline Diastolic BP (mmHg) & 76.6 & 12.4 & $77.2(12.7)$ & $76.1(12.2)$ & $<0.001$ & $0.38(0.17$ to 0.59$)$ & $<0.001$ \\
\hline Heart rate (bpm) & 79.0 & 13.0 & $79.4(13.1)$ & $78.8(12.2)$ & $<0.001$ & $0.25(0.03$ to 0.47$)$ & 0.02 \\
\hline Glucose (mg/dl) & 106.8 & 40.0 & $108.0(41.4)$ & $105.9(38.9)$ & $<0.001$ & $0.55(-0.17$ to 1.28$)$ & 0.14 \\
\hline Current smoker & $5,430.0$ & $10.5 \%$ & $9.40 \%$ & $11.30 \%$ & $<0.001$ & 0.92 (0.86 to 0.98$)$ & 0.01 \\
\hline \multicolumn{8}{|l|}{ DrinkAlcohol } \\
\hline Current & $5,418.0$ & $10.5 \%$ & $9.70 \%$ & $11.00 \%$ & $<0.001$ & 1.07 (1.00 to 1.14$)$ & 0.07 \\
\hline Previous & $2,143.0$ & $4.1 \%$ & $3.40 \%$ & $4.70 \%$ & & $1.15(1.04$ to 1.26$)$ & 0.004 \\
\hline Never & $44,290.0$ & $85.4 \%$ & $86.90 \%$ & $84.30 \%$ & & 1.09 (1.03 to 1.16$)$ & 0.003 \\
\hline Fruit intake (Days/week) & 3.0 & 2.5 & $2.99(2.49)$ & $3.04(2.48)$ & 0.03 & $0.10(0.06$ to 0.14$)$ & $<0.001$ \\
\hline Vegetable intake (Days/week) & 6.0 & 1.5 & $5.95(1.55)$ & $6.06(1.51)$ & $<0.001$ & $0.00(-0.03$ to 0.03$)$ & 0.87 \\
\hline
\end{tabular}


medRxiv preprint doi: https://doi.org/10.1101/2020.11.12.20229898; this version posted November 14,2020 . The copyright holder for this preprint (which was not certified by peer review) is the author/funder, who has granted medRxiv a license to display the preprint in perpetuity.

\section{All rights reserved. No reuse allowed without permission.}

\begin{tabular}{|c|c|c|c|c|c|}
\hline \begin{tabular}{l|}
$\begin{array}{l}\text { Control measures } \\
\text { in place }\end{array}$ \\
\end{tabular} & Bangladesh & North India & South India & Pakistan & Sri Lanka \\
\hline \begin{tabular}{|l|} 
Date start \\
\end{tabular} & 26 March 2020 & 25 March 2020 & 25 March 2020 & 16 March 2020 & 20 Mar 2020 \\
\hline Date ended & 31 May 2020 & $\begin{array}{l}31 \text { May phased out with unlock } \# 1 \\
\text { from } 1 \text { June, unlock } \# 2 \text { from } 1 \\
\text { July, unlock } \# 3 \text { from } 1 \text { August, } \\
\text { unlock } \# 4 \text { from } 1 \text { September with } \\
\text { restrictions in containment zones } \\
\text { till } 30 \text { September. }\end{array}$ & 31 August 2020 & 10 August 2020 & $\begin{array}{l}\text { Phased out from } 11 \text { May 2020; Completed by } 28 \\
\text { June } 2020\end{array}$ \\
\hline $\begin{array}{l}\text { School Closing } \\
\end{array}$ & \begin{tabular}{|l|}
$\begin{array}{l}\text { Extended nationwide domestic } \\
\text { restrictions on } 4 \text { August until at least } 31 \\
\text { AAgust amid a rise in cases, maintaining } \\
\text { the closure of all educational } \\
\text { institutions. } \\
\text { Confirmed on } 23 \text { August that all } \\
\text { educational institutes will remain closed } \\
\text { past September until the COVID-19 }\end{array}$ \\
\end{tabular} & \multicolumn{2}{|c|}{$\begin{array}{l}\text { Extended closures of schools, colleges, and coaching institutions on } \\
\text { 01 July until } 31 \text { July in both containment and non-containment zones. } \\
\text { Entered its "Unlock 3" phase of lockdown rollback on } 1 \text { August, } \\
\text { extending nationwide closures of all schools, colleges, and } \\
\text { educational and coaching institutions until } 31 \text { August }\end{array}$} & $\begin{array}{l}\text { Extended school closures on } 02 \text { July until the first week of } \\
\text { September, past the expected reopening date of } 16 \text { July. } \\
\text { Maintained closures on educational institutes in Khyber } \\
\text { Pakntunkhwa and Sindh until at least } 15 \text { September despite } \\
\text { the continued national reopening. }\end{array}$ & 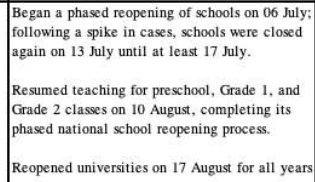 \\
\hline \begin{tabular}{|l|} 
Workplace closing \\
\end{tabular} & $\begin{array}{l}\text { Yes, with RMG factories started gradual } \\
\text { opening from April 27. } \\
\text { Extended nationwide domestic } \\
\text { restrictions on } 4 \text { August until at least } 31 \\
\text { August amid a rise in cases, restricting } \\
\text { busines hours to 20:00 daily; clouses of } \\
\text { non-essential businesses continue to } \\
\text { apply in designated localities under the } \\
\text { previous colour-coded zonal lockdown } \\
\text { syytem. }\end{array}$ & \multicolumn{2}{|c|}{$\begin{array}{l}\text { Allowed businesses in non-containment zones to reopen on } 01 \text { July, } \\
\text { with official recommendations for work-from-home and the staggering } \\
\text { of working hours; only essential services continue to be operational in } \\
\text { containment zones. } \\
\text { Entered its "Unlock 3" phase of lockdown rollback on } 1 \text { August, } \\
\text { permitting most businesses to reopen in all non-containment zones; } \\
\text { recreational facilities (including cinema halls, swimming pools, bars, } \\
\text { and assembly halls) remain closed nationwide until } 31 \text { August, while } \\
\text { yoga institutes and gymnasiums reopened on } 5 \text { August. }\end{array}$} & $\begin{array}{l}\text { Pakistan extended 'smart lockdowns' on } 02 \text { July for localities } \\
\text { in some provinces, including Punjab, Khyber Pakhtunkwa, and } \\
\text { Sindh, mandating the closure of non-essential businesses and } \\
\text { defining standard operating practices for essential busine sses. } \\
\text { Lifted the complete lockdown in Punjab province on } 3 \\
\text { AAgust; imposed in advance of the Eid-alal-Adha holiday, the } \\
\text { lockdown was rolled back two days earlier than scheduled, } \\
\text { allowing all busineseses to reopen weekdays from 9:00 to 19:00 } \\
\text { (except for recreational facilities, including restaurants, } \\
\text { beauty parlours, and cinemas). } \\
\text { Lifted restrictions on restaurants and some non-esential } \\
\text { tourism-related businesses in the week following } 10 \text { August, } \\
\text { while Khyber Pakhtunkhwa, Funjab, and Sindh provinces } \\
\text { maintained some restrictions on marriage halls and expo } \\
\text { centres until } 15 \text { September. }\end{array}$ & Yes \\
\hline \begin{tabular}{|l|} 
Cancel Public \\
Events
\end{tabular} & \begin{tabular}{|l|} 
Extended nationwide domestic \\
restrictions on 4 August until at least 31 \\
August amid a reise in cases, maintaining \\
a ban on all large public gatherings.
\end{tabular} & \multicolumn{2}{|c|}{$\begin{array}{l}\text { Announced the cancellation of all social, political, sports, religious, } \\
\text { entertainment, academic and cultural events from 01 July in both } \\
\text { containment and non-containment zones } \\
\text { Entered its "Unlock 3" phase of lockdown rollback on } 1 \text { August, } \\
\text { extending its nationwide prohibition of public events (including } \\
\text { social, political, entertainment, cultural, and religious functions) } \\
\text { until } 31 \text { August. }\end{array}$} & $\begin{array}{l}\text { Announced new requirements on religious congregations in } \\
\text { Khyber Pakhtunkhwa, Punjab, and Sindh, with all festivals } \\
\text { permitted with the condition of prior approval from } \\
\text { respective provincial governments and adherence to local } \\
\text { soPs }\end{array}$ & \\
\hline \begin{tabular}{|l|} 
Restrictions on \\
Gatherings
\end{tabular} & \begin{tabular}{|l|} 
Extended nationwide domestic \\
restrictions on 4 August until at least 31 \\
August amid a rise in cases, maintaining \\
a ban on large private gatherings; \\
restrictions of private gatherings to fewer \\
than 10 people continue to apply in \\
designated localities under the previous \\
colour-coded zonal lockdown system.
\end{tabular} & \multicolumn{2}{|c|}{$\begin{array}{l}\text { Extended a ban on large public gatherings on } 01 \text { July, while } \\
\text { restrictions on weddings were loosened to no more than } 50 \text { guests, and } \\
\text { funerals to no more than } 20 \text { guests } \\
\text { Maintained its restrictions on private gatherings under its National } \\
\text { Directives for COVIID-19 Management on } 1 \text { Aguust, including limits } \\
\text { on marriage-related gatherings at } 50 \text { people, and funerals at } 20 \\
\text { people. }\end{array}$} & $\begin{array}{l}\text { Announced on } 12 \text { August a phased approach to lifting sports- } \\
\text { related gatherings as part of its lockdown reopening; in the } \\
\text { current first phase, } 10 \text { or fewer people are permitted at } \\
\text { workouts and practices nationwide }\end{array}$ & \\
\hline \begin{tabular}{|l|}
$\begin{array}{l}\text { Close public } \\
\text { transport }\end{array}$ \\
\end{tabular} & $\begin{array}{l}\text { Resumed limited public transport } \\
\text { services on } 4 \text { August; capacity reductions } \\
\text { and social distancing measures are in } \\
\text { place on all rail services, and on bus } \\
\text { services operating in Dhaka and on long- } \\
\text { distance routes. }\end{array}$ & \multicolumn{2}{|c|}{$\begin{array}{l}\text { Resumed domestic flights and passenger trains on } 01 \text { July, metro rail } \\
\text { systems remain closed. } \\
\text { Entered its "Unlock 3" phase of lockdown rollback on } 1 \text { August, } \\
\text { extending its nationwide closure of all urban "Metro Rail" services } \\
\text { until } 31 \text { Aungust; domestic trains and ther local transports continue to } \\
\text { adhere to regional Standard Operating Procedures (SOPs) issued by the } \\
\text { Ministry of Health and Family Welfare. }\end{array}$} & $\begin{array}{l}\text { Continued reopening all public transport since } 10 \text { August with } \\
\text { SOPs for mitigating COVID-19 transmission in place }\end{array}$ & \\
\hline \begin{tabular}{|l|} 
Stay at home \\
requirements
\end{tabular} & $\begin{array}{l}\text { BANGLADESH: extended nationwide } \\
\text { domestic restrictions on } 4 \text { August until at } \\
\text { least } 31 \text { August amid a rise in cases, } \\
\text { recommending all residents to stay home } \\
\text { "to the extent possible"; requirements to } \\
\text { stay at home continue to apply in } \\
\text { designated localities under the previous } \\
\text { colour-coded zonal lockdown system. }\end{array}$ & \multicolumn{2}{|c|}{$\begin{array}{l}\text { Imposed a nightly curfew nationwide on } 01 \text { July, and general daytime } \\
\text { movements were restricted in containment zones except for the } \\
\text { operation of essential services. } \\
\text { Entered its "Unlock 3" phase of lockdown rollback on } 1 \text { August, } \\
\text { extending mandatory stay-at-home requirements in all containment } \\
\text { zones nationwide until } 31 \text { August, except for "essential activities". }\end{array}$} & $\begin{array}{l}\text { Directed citizens to stay confined in homes when subject to } \\
\text { 'smart lockdown' notifications in their locality as of } 02 \text { July. } \\
\text { Extended a complete lockdown in Balochistan province on } 3 \\
\text { August until 17 August, mandating residents to stay at home; } \\
\text { all recreational places (including beaches) reopened in Sindh } \\
\text { province on 4 August, ending a lockdown imposed in advance } \\
\text { of the Eid-al-Adha holiday. } \\
\text { Continued its withdrawal of stay-at-home measures across } \\
\text { various provinces since the } 10 \text { August reopening. }\end{array}$ & \\
\hline \begin{tabular}{|l|} 
Restrictions on \\
Internal movement
\end{tabular} & Yes & \multicolumn{2}{|c|}{$\begin{array}{l}\text { Maintained strict perimeter control in containment zones as of } 01 \\
\text { July, barring movement in or out of designated areas. } \\
\text { Entered its "Unlock 3" phase of lockdown rollback on } 1 \text { August, } \\
\text { maintaining "strict perimeter control" of all containment zones } \\
\text { nationwide until } 31 \text { August; all movement in or out of these zones } \\
\text { remains prohibited except for medical emergencies and the supply of } \\
\text { essential goods and services. } \\
\text { Requested state governments to lift all remaining inter-state } \\
\text { restrictions on the movement of goods and their conveyances in } \\
\text { compliance with a mandate under the current "Unlock 3" lockdown } \\
\text { rollback by the Ministry of Home Affairs }\end{array}$} & $\begin{array}{l}\text { Formalized restrictions on internal movement in its 'smart } \\
\text { lockdown' strategy as of } 02 \text { July, barring movement outside } \\
\text { containment areas }\end{array}$ & Yes \\
\hline \begin{tabular}{|l|} 
International \\
Travel Controls
\end{tabular} & & \multicolumn{2}{|c|}{\begin{tabular}{|l|} 
Extended its ban on all international flights on 01 July with the \\
exception of repatriation flights. \\
Entered its "Unlock 3" phase of lockdown rollback on 1 August, \\
maintaining its ban on all international air travel of passengers \\
nationwide, except where permitted by the Ministry of Home Affairs \\
(including for the repatriation of citizens).
\end{tabular}} & & \\
\hline Financial Support & Yes (for low SES) & \begin{tabular}{|l|} 
Yes (to beneficiaries of specific \\
national schemes and people with \\
below-poverty-line cards)
\end{tabular} & Yes (for low SES) & Yes (for low SES) & Yes (for low SES and informal workers) \\
\hline \begin{tabular}{|l|} 
Nutritional Support \\
\end{tabular} & Yes & Yes & Yes & Yes (for low SES) & Yes (for low SES and informal workers) \\
\hline
\end{tabular}

Note: SES = Socioeconomic status
Source: Oxford COVID-19 Government Response Tracker: Regional Report - South Asia \& Country collaborator

https://www.bsg.ox.ac.uk/research/research-projects/coronaviruss-government-responese-tracker 
medRxiv preprint doi: https://doi.org/10.1101/2020.11.12.20229898; this version posted November 14,2020 . The copyright holder for this preprint (which was not certified by peer review) is the author/funder, who has granted medRxiv a license to display the preprint in perpetuity. All rights reserved. No reuse allowed without permission.

Supplementary Table 4: COVID-19 Burden, knowledge and preventive behaviours

\begin{tabular}{|c|c|c|c|c|c|c|}
\hline & Total & Bangladesh & North India & South India & Pakistan & Sri Lanka \\
\hline \multicolumn{7}{|c|}{ (a) Had main COVID-19 symptom } \\
\hline$\%$ with any one symptom & $4.6 \%$ & $8.3 \%$ & $1.7 \%$ & $4.4 \%$ & $7.3 \%$ & $2.2 \%$ \\
\hline$\%$ with fever and cough & $1.0 \%$ & $1.1 \%$ & $0.4 \%$ & $3.0 \%$ & $1.4 \%$ & $0.1 \%$ \\
\hline$\%$ with swab test & $0.9 \%$ & $0.2 \%$ & $1.0 \%$ & $2.1 \%$ & $3.0 \%$ & $0.2 \%$ \\
\hline
\end{tabular}

(c) Knowledge on symptom

$\%$ answered Fever as a symptom of COVID-19

$\%$ answered Dry cough as a symptom

$\%$ answered Tiredness as a symptom

$\%$ answered Muscle/joint pain as a symptom

$\%$ answered Shortness of breath as a symptom

$\%$ answered Runny or blocked nose as a symptom

$\%$ answered Sore throat as a symptom

$\%$ answered Loss of smell as a symptom

$\%$ answered Loss of appetite as a symptom

$\%$ answered Productive cough as a symptom

$\%$ answered Diarrhea as a symptom

$\%$ answered Headache as a symptom

$\%$ answered Vomiting as a symptom

$\begin{array}{rrrrrr}90.1 \% & 87.0 \% & 95.0 \% & 85.5 \% & 91.3 \% & 91.9 \% \\ 79.5 \% & 81.4 \% & 82.3 \% & 80.5 \% & 71.9 \% & 77.2 \% \\ 23.2 \% & 3.6 \% & 30.0 \% & 48.2 \% & 47.1 \% & 20.2 \% \\ 22.9 \% & 11.6 \% & 26.0 \% & 28.4 \% & 41.0 \% & 24.8 \% \\ 49.5 \% & 40.4 \% & 56.3 \% & 59.3 \% & 53.0 \% & 48.6 \% \\ 43.5 \% & 42.8 \% & 32.8 \% & 32.5 \% & 40.7 \% & 57.5 \% \\ 49.4 \% & 53.5 \% & 40.4 \% & 44.7 \% & 29.5 \% & 59.3 \% \\ 5.4 \% & 0.1 \% & 8.6 \% & 11.0 \% & 5.5 \% & 6.0 \% \\ 2.1 \% & 0.5 \% & 2.0 \% & 3.4 \% & 2.9 \% & 3.0 \% \\ 7.6 \% & 2.4 \% & 6.2 \% & 14.2 \% & 4.1 \% & 11.8 \% \\ 5.4 \% & 8.7 \% & 5.2 \% & 5.7 \% & 2.7 \% & 2.7 \% \\ 20.1 \% & 21.1 \% & 22.3 \% & 10.8 \% & 4.6 \% & 26.4 \% \\ 3.4 \% & 2.9 \% & 5.6 \% & 5.7 \% & 1.7 \% & 1.9 \% \\ & & & & & \\ 78.4 \% & 71.4 \% & 72.3 \% & 79.0 \% & 75.5 \% & 89.9 \% \\ 66.4 \% & 72.5 \% & 76.0 \% & 67.9 \% & 64.4 \% & 53.6 \% \\ 45.1 \% & 22.5 \% & 56.1 \% & 55.1 \% & 54.3 \% & 53.1 \% \\ 32.9 \% & 12.2 \% & 33.2 \% & 47.6 \% & 36.7 \% & 45.6 \% \\ 6.2 \% & 1.2 \% & 2.5 \% & 11.9 \% & 7.3 \% & 10.9 \% \\ 1.4 \% & 0.2 \% & 0.6 \% & 3.9 \% & 3.3 \% & 1.5 \%\end{array}$

(e) Knowledge of prevention measures

Wearing a face mask while going out

Staying at least 1-2 metres away from other people

$99.6 \%$

$99.5 \%$

$99.9 \%$

$99.9 \%$

$99.5 \%$

$99.9 \%$

$98.8 \%$

$99.4 \%$

$99.8 \%$

$99.7 \%$

$98.7 \%$

$99.8 \%$

$96.7 \%$

$98.7 \%$

$99.5 \%$

$96.7 \%$

$98.4 \%$

$96.9 \%$

$87.5 \%$

$96.7 \%$

$99.8 \%$

$96.0 \%$

$98.5 \%$

Avoiding social gatherings

Avoiding public transportation

$98.2 \%$

$96.0 \%$

$95.4 \%$

$86.9 \%$

$95.7 \%$

$99.4 \%$

$92.4 \% \quad 99.1 \%$

$83.0 \%$

$94.3 \%$

$99.6 \%$

$89.2 \%$

$88.3 \%$

$81.3 \%$

$93.7 \%$

$99.4 \%$

$91.9 \%$

$91.0 \%$

$95.4 \%$

$86.1 \%$

$79.5 \%$

$95.9 \%$

$97.9 \%$

(f) Implementation: In the last 2 weeks ...

Not wearing a face mask outside

$39.3 \%$

$8.3 \%$

$67.1 \%$

$13.0 \%$

$22.4 \%$

Not followed 1-2 metres away from other people

$7.3 \%$

$17.1 \%$

$1.4 \%$

$0.9 \%$

$16.1 \%$

$30.4 \%$

$43.1 \%$

Leave shoes outside the main entrance of your house

$41.0 \%$

Went out of the house for non-essential reasons

$18.8 \%$

$24.7 \%$

Joined social gatherings other than household members

$74.9 \%$

$66.0 \%$

$5.9 \%$

$81.9 \%$

$1.7 \%$

$4.8 \%$

$0.8 \%$

$1.8 \%$

$12.5 \%$

$0.7 \%$

$39.8 \% \quad 1.1 \%$

Used public transport

$86.2 \%$

$13.5 \%$

$13.2 \%$

$57.8 \%$

$69.9 \%$

$90.1 \%$

$40.3 \% \quad 16.5 \%$

(g) Resources available at home for use

Soap/detergent/hand wash/

$99.8 \%$

$5.7 \%$

$28.7 \%$

$30.1 \%$

$8.3 \%$

Hand sanitizer/ alcohol hand rub

$52.8 \%$

$99.7 \%$

$99.9 \%$

$99.7 \%$

$99.6 \%$

$99.8 \%$

Face mask

$31.8 \%$

$83.1 \%$

$64.0 \%$

$51.4 \%$

$47.2 \%$

Gloves

$91.6 \%$

$95.4 \%$

$92.8 \%$

$99.2 \%$

Tissue paper/paper napkin

$20.2 \%$

$25.7 \%$

$22.5 \%$

$47.8 \%$

$40.1 \%$

$48.2 \%$

Water supply at home

$26.5 \%$

$17.6 \%$

$58.3 \%$

$59.2 \%$

$63.2 \%$

$22.4 \%$

$69.7 \%$

$90.3 \%$

$77.1 \%$

Self-isolate room

$40.6 \%$

$54.6 \%$

$36.7 \%$

$51.6 \%$

$57.9 \%$

6152

3934

2534

8382 
medRxiv preprint doi: https://doi.org/10.1101/2020.11.12.20229898; this version posted November 14, 2020. The copyright holder for this preprint (which was not certified by peer review) is the author/funder, who has granted medRxiv a license to display the preprint in perpetuity. All rights reserved. No reuse allowed without permission. 
medRxiv preprint doi: https://doi.org/10.1101/2020.11.12.20229898; this version posted November 14, 2020. The copyright holder for this preprint (which was not certified by peer review) is the author/funder, who has granted medRxiv a license to display the preprint in perpetuity.

\section{All rights reserved. No reuse allowed without permission.}

\begin{tabular}{|c|c|c|c|c|c|c|c|c|c|c|c|c|c|c|c|c|c|c|c|c|c|c|c|c|}
\hline & \multirow{2}{*}{\multicolumn{10}{|c|}{ Group 1: COVID-19 burden, knowledge, and preventative behaviors }} & \multirow{2}{*}{\multicolumn{10}{|c|}{ Group 2: COVID-19 on chroaic diksase }} & \multirow{2}{*}{\multicolumn{4}{|c|}{ Group 3: Social and financial circumstances }} \\
\hline & \multirow{2}{*}{\multicolumn{2}{|c|}{$\begin{array}{l}\text { At kast } 1 \text { main } \\
\text { COVID } \\
\text { symptom }\end{array}$}} & \multirow{2}{*}{\multicolumn{2}{|c|}{$\begin{array}{c}\text { Felh down \& } \\
\text { depressed }\end{array}$}} & \multirow{2}{*}{\multicolumn{2}{|c|}{$\begin{array}{l}\text { Felf nervous \& } \\
\text { anxious }\end{array}$}} & & & & & & & & & & & & & & & & & & \\
\hline & & & & & & & \multicolumn{2}{|c|}{$\begin{array}{c}\text { Weaker } \\
\text { knowledge of } \\
\text { symptoms \& }\end{array}$} & \multicolumn{2}{|c|}{$\begin{array}{c}\text { Poorer } \\
\text { implementation } \\
\text { of preventive }\end{array}$} & \multicolumn{2}{|c|}{$\begin{array}{l}\text { Run out med of } \\
\text { no ascess doc }\end{array}$} & \multicolumn{2}{|c|}{$\begin{array}{c}\text { Current tobaceo } \\
\text { use }\end{array}$} & \multicolumn{2}{|c|}{ Current drink } & \multicolumn{2}{|c|}{ Worse FV diet } & \multicolumn{2}{|c|}{$\begin{array}{l}\text { Less physical } \\
\text { ectivity }\end{array}$} & \multicolumn{2}{|c|}{ Employment loss } & \multicolumn{2}{|c|}{$\begin{array}{l}\text { Worse financial } \\
\text { situation }\end{array}$} \\
\hline & OR & (SE) & $\mathrm{OR}$ & (SE) & OR & (SE) & OR & (SE) & OR & (SE) & OR & (SE) & $\mathrm{OR}$ & (SE) & $\mathrm{OR}$ & (SE) & OR & (SE) & $\mathrm{OR}$ & (SE) & OR & (SE) & $\mathrm{OR}$ & (SE) \\
\hline \multicolumn{25}{|l|}{ Prior income } \\
\hline Quintile 1 (poot) & 1 & & 1 & & 1 & & 1 & & 1 & & 1 & & 1 & & 1 & & 1 & & 1 & & 1 & & 1 & \\
\hline Quintile 2 & 1.017 & $(0.091)$ & 0.949 & $(0.043)$ & 1.006 & $(0.045)$ & $0.824^{\circ}$ & $(0.041)$ & 1.005 & $(0.056)$ & 0.853 & $(0.100)$ & 0.991 & $(0.059)$ & 0.963 & $(0.183)$ & 1.039 & $(0.051)$ & 1.024 & $(0.047)$ & 0.919 & $(0.040)$ & 0.987 & $(0.047)$ \\
\hline Quintile 3 & 0.929 & $(0.087)$ & 0.946 & $(0.043)$ & 0.973 & $(0.044)$ & $0.826^{*}$ & $(0.042)$ & 0.961 & $(0.056)$ & 0.903 & $(0.096)$ & 1.036 & $(0.063)$ & $1.464^{*}($ & $(0.228)$ & $1.128^{*}$ & $(0.054)$ & $1.109^{*}$ & $(0.050)$ & 0.903 * & $(0.038)$ & $0.913^{\circ}$ & $(0.042)$ \\
\hline Quintile 4 & 0.862 & $(0.088)$ & 0.944 & $(0.047)$ & 0.92 & $(0.046)$ & $0.773^{*}$ & $(0.043)$ & $0.826^{\circ}$ & $(0.053)$ & $0.746^{*}$ & $(0.089)$ & 1.001 & $(0.066)$ & $1.606 *$ & $(0.256)$ & 1037 & $(0.054)$ & 1.049 & $(0.051)$ & 0.916 & $\gamma_{(0.042)}$ & $0.726^{\circ}$ & $(0.035)$ \\
\hline Quintile 5 (rich) & 0.965 & (0.095) & $0.8377^{\circ}$ & $(0.042)$ & 0.832 & $(0.042)$ & $0.674^{\circ}$ & $(0.039)$ & $0.757^{*}$ & (0.050) & $0.709 \cdot$ & $(0.085)$ & 1.006 & $(0.068)$ & $1.703 \cdot 8$ & $(0.272)$ & $1.161^{\circ}$ & $(0.062)$ & 0.992 & (0.049) & $0.828^{\circ}$ & $(0.038)$ & $0520^{\circ}$ & $(0.025)$ \\
\hline \multicolumn{25}{|c|}{ 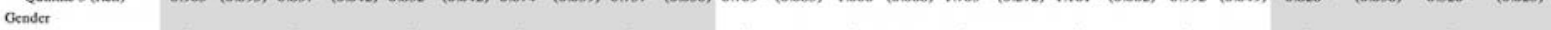 } \\
\hline Male & 1 & & 1 & & 1 & & 1 & & 1 & & 1 & & 1 & & 1 & & 1 & & 1 & & 1 & & 1 & \\
\hline \multirow{2}{*}{\multicolumn{25}{|c|}{ 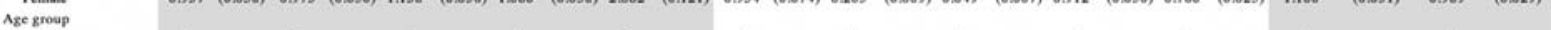 }} \\
\hline & & & & & & & & & & & & & & & & & & & & & & & & \\
\hline $18.29 \mathrm{yr}$ & 1 & & 1 & & 1 & & 1 & & 1 & & 1 & & 1 & & 1 & & 1 & & 1 & & 1 & & 1 & \\
\hline $30.39 \mathrm{yt}$ & 0.974 & $(0.092)$ & $1.151^{\circ}$ & (0.056) & $1.179^{*}$ & $(0.057)$ & 1.121 & $(0.066)$ & 0.956 & (0.058) & 0.959 & (0.195) & $1.420^{*}$ & $(0.103)$ & $1.793^{*}$ \& & $(0.296)$ & 1.018 & $(0.054)$ & $0.796^{*}$ & $(0.039)$ & 1.008 & $(0.045)$ & 0.969 & $(0.047)$ \\
\hline $40.49 \mathrm{yr}$ & 0.86 & $(0.086)$ & $1.154^{*}$ & (0.058) & $1.234^{*}$ & $(0.062)$ & $1.148^{\circ}$ & $(0.070)$ & 0.909 & (0.059) & 0.77 & $(0.151)$ & $1.930^{*}$ & $(0.142)$ & $1.679^{*}$ & $(0.271)$ & 0.989 & $(0.054)$ & $0.831^{*}$ & $(0.042)$ & 0.98 & (0.045) & $0.856^{\circ}$ & $(0.042)$ \\
\hline $50-59 \mathrm{yr}$ & 0.876 & $(0.094)$ & 1.074 & (0.058) & $1.187^{\circ}$ & $(0.064)$ & $1547^{\circ}$ & $(0.099)$ & 1.052 & $(0.074)$ & 0.694 & $(0.136)$ & $2.134^{*}$ & $(0.165)$ & 1.38 & $(0.238)$ & 0.971 & $(0.057)$ & $0.870^{\circ}$ & $(0.047)$ & 0.943 & $(0.047)$ & $0.743^{*}$ & $(0.039)$ \\
\hline \multirow{2}{*}{\multicolumn{25}{|c|}{ 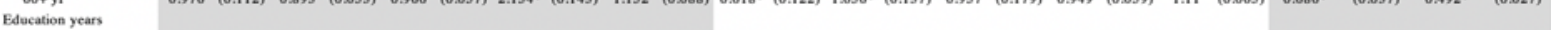 }} \\
\hline & & & & & & & & & & & & & & & & & & & & & & & & \\
\hline $0 \mathrm{yr}$ & 1 & & 1 & & 1 & & 1 & & 1 & & 1 & & 1 & & 1 & & 1 & & 1 & & 1 & & 1 & \\
\hline $1.7 \mathrm{yr}$ & 1.137 & $(0.106)$ & 0.924 & $(0.042)$ & 0.965 & $(0.043)$ & $0.782^{\circ}$ & $(0.038)$ & $0.851^{*}$ & $(0.046)$ & 1.179 & $(0.140)$ & $0.679^{*}$ & $(0.039)$ & 0.812 & $(0.185)$ & $1.324^{*}$ & $(0.069)$ & $0.886^{*}$ & $(0.043)$ & 0.969 & $(0.042)$ & $0.887^{\circ}$ & $(0.044)$ \\
\hline $7.10 \mathrm{yr}$ & 1.211 & $(0.120)$ & $0.992 \pi$ & (0.048) & 1.0197 & $(0.049)$ & $0.592^{*}$ & $(0.032)$ & $0.858^{*}$ & $(0.052)$ & 0.87 & $(0.113)$ & $0.517^{*}$ & $(0.033)$ & 0.983 & $(0.216)$ & $1.138^{\circ}$ & $(0.065)$ & $0.825^{\circ}$ & $(0.043)$ & 0.913 & $(0.042)$ & $0.752^{*}$ & $(0.039)$ \\
\hline $10-13 \mathrm{yr}$ & $1.423^{*}$ & $(0.140)$ & $0.884^{*}$ & $(0.042)$ & $0.881^{\circ}$ & $(0.043)$ & $0.463^{\circ}$ & $(0.026)$ & $0.703^{\circ}$ & $(0.045)$ & 0.809 & $(0.101)$ & $0.392^{\circ}$ & $(0.026)$ & 0.768 & $(0.164)$ & $1.256^{*}$ & $(0.070)$ & $0.782^{\circ}$ & $(0.040)$ & $0.800^{\circ}$ & $(0.037)$ & $0.550^{\circ}$ & $(0.027)$ \\
\hline $13+y t$ & $1.430^{\circ}$ & $(0.184)$ & 0.885 & $(0.060)$ & $0.810^{\circ}$ & $(0.055)$ & $0.365^{\circ}$ & $(0.030)$ & $0.593^{\circ}$ & $(0.054)$ & $0.677^{\circ}$ & $(0.112)$ & $0.216^{\circ}$ & $(0.021)$ & 0.682 & $(0.166)$ & $1.254^{\circ}$ & $(0.088)$ & $0.794^{*}$ & $(0.052)$ & $0.580^{\circ}$ & $(0.037)$ & $0.315^{\circ}$ & $(0.020)$ \\
\hline \multicolumn{25}{|c|}{ Prior chronic condition } \\
\hline No & 1 & & 1 & & 1 & & 1 & & 1 & & 1 & & 1 & & 1 & & 1 & & 1 & & 1 & & 1 & \\
\hline Yes & $1315^{*}$ & $(0.097)$ & $1.167^{*}$ & $(0.036)$ & $1.117^{*}$ & $(0.035)$ & 0.948 & $(0.034)$ & 0.954 & $(0.039)$ & $1.537^{\circ}$ & $(0.211)$ & 0.922 & $(0.039)$ & 1.021 & $(0.094)$ & $0.913^{*}$ & $(0.031)$ & $1.074^{*}$ & $(0.034)$ & 0.997 & $(0.029)$ & 1.008 & $(0.031)$ \\
\hline Constant & $0.017^{*}$ & $(0.004)$ & $0.224^{*}$ & $(0.034)$ & $0.189^{\circ}$ & $(0.030)$ & $0.136^{*}$ & $(0.027)$ & $0.030^{\circ}$ & $(0.008)$ & $0.147^{*}$ & $(0.039)$ & $0.157^{*}$ & $(0.028)$ & $0.013^{*}$ & $(0.004)$ & $0.197^{*}$ & $(0.027)$ & $6.721^{\circ}$ & (1.348) & $0.436^{*}$ & $(0.050)$ & $5.343^{\circ}$ & $(0.896)$ \\
\hline $\mathrm{N}$ & 29449 & & 29449 & & 29449 & & 28497 & & 29449 & & 7518 & & 29449 & & 29449 & & 29449 & & 29449 & & 29421 & & 29449 & \\
\hline
\end{tabular}

Notc:
OR=Odds Ratio, SE=Standard errors, FV=fruih vegetable, yrayear, N=sample, SES=Sociocconomic status: * = 5\% significant

All dependent variables are binary. All regressioas use multi-level logisic regression modeling (first level individual, second level surveilance sice) 
medRxiv preprint doi: https://doi.org/10.1101/2020.11.12.20229898; this version posted November 14,2020 . The copyright holder for this preprint (which was not certified by peer review) is the author/funder, who has granted medRxiv a license to display the preprint in perpetuity.

All rights reserved. No reuse allowed without permission.

Supplementary Table 6: COVID-19 and access to medications

\begin{tabular}{|c|c|c|c|c|c|c|}
\hline & Total & Bangladesh & North India & South India & Pakistan & Sri Lanka \\
\hline (a) Of all sample, on routine medications & $23.9 \%$ & $19.3 \%$ & $14.6 \%$ & $24.5 \%$ & $17.8 \%$ & $36.9 \%$ \\
\hline (b) Of those on routine meds, run out of any meds (\%) & $15.1 \%$ & $13.8 \%$ & $17.7 \%$ & $20.1 \%$ & $11.8 \%$ & $13.9 \%$ \\
\hline \multicolumn{7}{|l|}{ (c) Of those run out of meds, types of medications } \\
\hline Run out: Anti-diabetic & $60.9 \%$ & $\mathrm{n} / \mathrm{a}$ & $56.2 \%$ & $76.5 \%$ & $68.6 \%$ & $53.5 \%$ \\
\hline Run out: Anti-hypertensive & $43.8 \%$ & $\mathrm{n} / \mathrm{a}$ & $40.5 \%$ & $34.8 \%$ & $58.8 \%$ & $47.3 \%$ \\
\hline Run out: Aspirin or clopidogrel & $8.6 \%$ & $\mathrm{n} / \mathrm{a}$ & $2.5 \%$ & $10.7 \%$ & $9.8 \%$ & $9.5 \%$ \\
\hline Run out: Statin & $8.2 \%$ & $\mathrm{n} / \mathrm{a}$ & $2.5 \%$ & $0.5 \%$ & $2.0 \%$ & $14.9 \%$ \\
\hline Run out: Pain killers & $6.7 \%$ & $\mathrm{n} / \mathrm{a}$ & $9.1 \%$ & $3.7 \%$ & $11.8 \%$ & $6.8 \%$ \\
\hline Run out: Inhaler & $5.6 \%$ & $\mathrm{n} / \mathrm{a}$ & $4.1 \%$ & $1.6 \%$ & $0.0 \%$ & $8.9 \%$ \\
\hline Run out: Cough medications & $1.6 \%$ & $\mathrm{n} / \mathrm{a}$ & $3.3 \%$ & $0.0 \%$ & $2.0 \%$ & $1.9 \%$ \\
\hline \multicolumn{7}{|l|}{ (d) Of those run out meds, reason for running out } \\
\hline Lockdown restricted me from going out & $50.9 \%$ & $8.5 \%$ & $55.4 \%$ & $71.7 \%$ & $17.0 \%$ & $67.1 \%$ \\
\hline Unable to afford & $16.7 \%$ & $48.5 \%$ & $6.3 \%$ & $4.1 \%$ & $47.2 \%$ & $5.1 \%$ \\
\hline Unable to go out for other reasons & $9.1 \%$ & $17.0 \%$ & $6.9 \%$ & $5.2 \%$ & $17.0 \%$ & $6.5 \%$ \\
\hline Was afraid of going out due to fear of COVID-19 infecti & $7.7 \%$ & $3.8 \%$ & $13.8 \%$ & $2.6 \%$ & $13.2 \%$ & $9.3 \%$ \\
\hline Pharmacy out of stock & $6.8 \%$ & $5.5 \%$ & $10.1 \%$ & $7.2 \%$ & $3.8 \%$ & $6.5 \%$ \\
\hline Others & $4.7 \%$ & $16.2 \%$ & $1.3 \%$ & $1.6 \%$ & $\mathrm{n} / \mathrm{a}$ & $1.6 \%$ \\
\hline Government medicine out of stock & $4.1 \%$ & $0.4 \%$ & $6.3 \%$ & $7.7 \%$ & $1.9 \%$ & $3.9 \%$ \\
\hline Sample & 29809 & 8807 & 6152 & 3934 & 2534 & 8382 \\
\hline
\end{tabular}

Note: n/a: Data not available 
medRxiv preprint doi: https://doi.org/10.1101/2020.11.12.20229898; this version posted November 14, 2020. The copyright holder for this preprint (which was not certified by peer review) is the author/funder, who has granted medRxiv a license to display the preprint in perpetuity. All rights reserved. No reuse allowed without permission.

Supplementary Figure 7: Benefit calculation of smoking cessation

\begin{tabular}{|c|c|c|c|}
\hline Baseline scenario & N/1000 & Incidence of CVD & Incidence of Lung Cancer \\
\hline Non smokers & 756 & $756^{\mathrm{a}}$ & $756^{\mathrm{b}}$ \\
\hline Current smokers & 244 & $244 \mathrm{a} \times 3=732^{\mathrm{a}}$ & $244 \mathrm{~b} \times 10=2440^{\mathrm{b}}$ \\
\hline Ex smokers & 0 & 0 & 0 \\
\hline Total & 1000 & $1488^{\mathrm{a}}$ & $3196^{b}$ \\
\hline Post-Pandemic & $\mathrm{N} / \mathbf{1 0 0 0}$ & Incidence of CVD & Incidence of Lung Cancer \\
\hline Non smokers & 756 & $756^{\mathrm{a}}$ & $756^{\mathrm{b}}$ \\
\hline Current smokers & 145 & $145 \mathrm{a} \times 3=435^{\mathrm{a}}$ & $145 \mathrm{~b} \times 10=1450^{\mathrm{b}}$ \\
\hline Ex smokers & 99 & $99^{\mathrm{a}}$ & $99 \mathrm{~b} \times 2=188^{b}$ \\
\hline Total & 1000 & $1290^{\mathrm{a}}$ & $2394^{\mathrm{b}}$ \\
\hline Predicted risk reduction & & $13.3 \%$ & $25.1 \%$ \\
\hline
\end{tabular}

Assumptions

Smoking cessation is maintained longterm

Incidence of CVD in non-smokers is 'a'

Incidence of lung cancer in non-smokers is ' $\mathrm{b}$ '

Smoking increases risk of CVD approximately 3 fold

Smoking increases risk of lung cancer approximately 10 fold

Risk of CVD in ex-smokers normalises to that of non-smokers in the long term

Risk of lung cancer remains elevated approximately 2 -fold in ex-smokers compared to non-smokers, even over the long term.

Refs

https://pubmed.ncbi.nlm.nih.gov/16189363/

https://www.nejm.org/doi/full/10.1056/NEJM198512123132404 
medRxiv preprint doi: https://doi.org/10.1101/2020.11.12.20229898; this version posted November 14,2020 . The copyright holder for this preprint (which was not certified by peer review) is the author/funder, who has granted medRxiv a license to display the preprint in perpetuity. All rights reserved. No reuse allowed without permission.

Supplementary Table 8: COVID-19 and social and financial support

\begin{tabular}{|c|c|c|c|c|c|c|}
\hline & Total & Bangladesh & North India & South India & Pakistan & Sri Lanka \\
\hline \multicolumn{7}{|l|}{ (a) Shopping for groceries and food } \\
\hline Before lockdown & $20.6 \%$ & $3.8 \%$ & $26.6 \%$ & $64.4 \%$ & $17.4 \%$ & $14.2 \%$ \\
\hline After lockdown (Last 2 weeks) & $26.9 \%$ & $7.2 \%$ & $26.7 \%$ & $49.8 \%$ & $16.7 \%$ & $40.0 \%$ \\
\hline$\%$ Difference & $30.7 \%$ & $91.0 \%$ & $0.3 \%$ & $-22.6 \%$ & $-4.1 \%$ & $181.9 \%$ \\
\hline \multicolumn{7}{|l|}{ (b) Picking up medications } \\
\hline Before & $10.2 \%$ & $2.7 \%$ & $5.0 \%$ & $38.2 \%$ & $9.4 \%$ & $9.1 \%$ \\
\hline After & $8.7 \%$ & $1.7 \%$ & $3.9 \%$ & $23.3 \%$ & $7.4 \%$ & $13.2 \%$ \\
\hline$\%$ Difference & $-14.6 \%$ & $-35.0 \%$ & $-22.3 \%$ & $-38.9 \%$ & $-21.1 \%$ & $44.6 \%$ \\
\hline \multicolumn{7}{|l|}{ (c) Donated or subsidised food } \\
\hline Before & $6.1 \%$ & $3.7 \%$ & $10.1 \%$ & $12.4 \%$ & $5.2 \%$ & $3.0 \%$ \\
\hline After & $13.2 \%$ & $7.6 \%$ & $12.6 \%$ & $14.8 \%$ & $4.2 \%$ & $21.5 \%$ \\
\hline$\%$ Difference & $115.7 \%$ & $103.3 \%$ & $25.0 \%$ & $19.3 \%$ & $-19.5 \%$ & $611.9 \%$ \\
\hline \multicolumn{7}{|l|}{ (d) Monetary support } \\
\hline Before & $6.6 \%$ & $3.7 \%$ & $3.3 \%$ & $19.4 \%$ & $2.7 \%$ & $7.3 \%$ \\
\hline After & $20.1 \%$ & $3.3 \%$ & $4.4 \%$ & $21.2 \%$ & $2.4 \%$ & $54.2 \%$ \\
\hline$\%$ Difference & $203.1 \%$ & $-12.2 \%$ & $33.2 \%$ & $9.4 \%$ & $-11.6 \%$ & $638.2 \%$ \\
\hline Sample & 29809 & 8807 & 6152 & 3934 & 2534 & 8382 \\
\hline
\end{tabular}

Note: P-values for each \% difference among total sample $<0.001$ 
medRxiv preprint doi: https://doi.org/10.1101/2020.11.12.20229898; this version posted November 14, 2020. The copyright holder for this preprint (which was not certified by peer review) is the author/funder, who has granted medRxiv a license to display the preprint in perpetuity.

Supplementary Figure 1: Forest plot of responser bias

\section{Study}

Gender: Female

Age: $<30$ yrs old

Age: $30-50$ yrs old

Age: $>50$ yrs old

Education: Primary school or below

Education: Secondary school

Education: Postgraduate

Marital: Never Married

Marital: Currently married

Marital: Widowed

Marital: Separated or Divorced

Occupation: Government employee

Occupation: Non-government employee

Occupation: Self-employed

Occupation: Non-paid

Occupation: Student

Occupation: Homemaker

Occupation: Retired

Occupation: Unemployed (able to work)

Occupation: Unemployed (unable to work)

Hypertension history

Diabetes history

Heart attack history

Tobacco: Current smoker

Alcohol: Current drinker

Alcohol: Previous drinker

Alcohol: Never
Effect Size with $95 \% \mathrm{Cl}$

0.84 [ $0.81,0.87]$

1.15 [ $1.10,1.20]$

1.10 [1.06, 1.14]

0.83 [ $0.80,0.86]$

0.82 [ $0.78,0.86]$

1.19 [ 1.14, 1.24]

1.11 [ $1.03,1.19]$

$1.04[0.96,1.12]$

1.15 [ 1.09, 1.21]

0.89 [ $0.82,0.96]$

0.78 [ 0.66, 0.90]

1.19 [ $1.08,1.30]$

1.01 [ 0.96, 1.06]

0.93 [ $0.89,0.97]$

1.02 [ $0.69,1.35]$

1.26 [ 1.08, 1.44]

1.03 [ $0.98,1.08$ ]

1.30 [ $1.18,1.42]$

1.07 [ 1.00, 1.14]

0.93 [ $0.84,1.02]$

1.11 [ 1.06, 1.16]

1.13 [ 1.08, 1.18]

1.01 [ $0.90,1.12]$

0.92 [ 0.86, 0.98]

1.07 [ $1.00,1.14]$

1.15 [ 1.04, 1.26]

1.09 [ $1.03,1.15]$

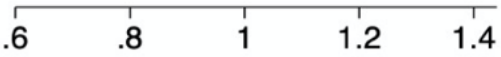

